\title{
Nailing Jello to a Wall: A Uniform Approach for Adjudicating Insurance Coverage Disputes in Products Liability Cases with Delayed Manifestation Injuries and Damages
}

\author{
Tung Yin $\dagger$
}

Products liability cases involving delayed manifestation injuries and damages pose two fundamental problems for Commercial General Liability ("CGL") insurers and the courts. First, courts must resolve whether each individual claim constitutes a separate indemnifiable occurrence. Second, when liability spans multiple policy periods, courts must allocate indemnification among multiple insurers. Although CGL policies generally contain similar terms, courts have not yet devised a uniform approach for determining what constitutes an indemnifiable occurrence, which CGL policies are triggered, and how to allocate indemnification among insurers. After survcying the shortcomings of the present situation, this Comment presents a Pareto optimal approach for resolving delayed-manifestation insurance coverage disputes. The author starts from the premise that all injuries and damages stemming from the same proximate cause should be treated as a single occurrence. He proposes that courts should consider a policy triggered whenever an occurrence causes damage during that policy's coverage period, regardless of whether other policies have been triggered by that occurrence. Under the proposal, an insurer is responsible for indemnifying the insured for whatever damages and injuries actually occur during that insurer's coverage period, subject to deductibles and policy limits. Where a plaintiff cannot prove precisely when damages occurred, the proposed rule apportions damages according to a rule of convenience. The author identifies several potential benefits to the proposal, including reduced liti-

Copyright (C) 1995 California Law Review, Inc.

i Law Clerk to the Honorable Edward Rafeedie, United States District Court Judge for the Central District of California. J.D. 1995, University of California, Berkeley. I would like to thank Professor Kenneth Abraham of the University of Virginia, Professor John Dwyer, Professor Jan Vetter, Jennifer Gillum, and Amy Toro for their insightful comments and criticisms at various stages of writing; Christopher Sanchirico for looking over the economic analysis; and David Schack of Mitchell, Silberberg \& Knupp for introducing me to the world of insurance coverage disputes. It goes without saying that the views expressed herein are entirely my own, as are any errors or omissions. 
gation and transaction costs, lower premiums, and more predictable legal outcomes.

\section{INTRODUCTION}

In the early 1970s, Champion International Company, a distributor of vinyl coverings, was hit by numerous lawsuits alleging that it had sold defective paneling to manufacturers of boats and motor vehicles. ${ }^{1}$ Some 1400 vehicles were damaged, with the total aggregate liability approaching $\$ 1.6$ million. No individual claim, however, exceeded $\$ 5000 .^{2}$ Champion turned to its Commercial General Liability ("CGL") insurance policy for indemnification from the products liability claims.

A CGL policy indemnifies an insurcd business for sums it becomes legally obligated to pay, such as those resulting from lawsuits. CGL policies are structured somewhat like third-party automobile insurance policies, with deductibles ${ }^{3}$ and limits, ${ }^{4}$ and they commonly use standardized language. ${ }^{5}$ In Champion's case, the CGL policy covered damages on an "occurrence" basis;" that is, the $\$ 5000$ deductible and policy limits were tied to each occurrence of an injury. ${ }^{7}$

If each separate claim against Champion had counted as one occurrence, the company would have been entitled to no CGL indemnification, because the $\$ 5000$ deductible would have exceeded the damages in each case. Not surprisingly, Champion's insurer advanced this position. ${ }^{8}$ Champion, on the other hand, argued that there was but one occurrence, "namely, the delivery of defective panels." Under this theory, Champion would be entitled to indemmification up to its policy limit, minus the $\$ 5000$ deductible.

In this case, Champion (the msured) and its insurer took their respective positions because there were numerous claims of damages, each of which was relatively small in comparison to the aggregate. In a case with the opposite situation of few claims or claims for relatively large damages, however, the insured and insurer would probably switch positions. The

1. Champion Int'l Corp. v. Continental Casualty Co., 546 F.2d 502, 504 (2d Cir. 1976), cert. denied, 434 U.S. 819 (1977).

2. Id. at 504-05.

3. A deductible represents a specific sum that is deducted from the amount that the insurer is obligated to pay the insured. KenNeth S. Abraham, Distributing Rusk: INSURANCE, Legal TheorY, and Public Policy 15 n.12 (1986).

4. See Kenneth S. Abraham, Insurance Law and Regulation: Cases and Materials 43948 (1990) (setting forth sample CGL policy).

5. ROBERT H. JERRY, 1l, UNDERSTANDING INSURANCE LAW 97, 99 (1987).

6. Champion, 546 F.2d at 505.

7. Id. "'Occurrence' means an accident, including continuous or repeated exposure to substantially the same general harmful conditions." АвRAHAM, supra note 4, at 448.

8. Champion, 546 F.2d at 505.

9. Id. 
insured would want to treat each claim as a separate occurrence, so that it could collect up to the policy limit for each injury.

For example, in the mid-1980s, the Red Cross was served with a series of complaints alleging that it had handled HIV-contaminated blood ncgligently. ${ }^{10}$ The Red Cross wanted each complaint treated as a separate occurrence, ${ }^{11}$ because its CGL policy covered up to $\$ 1$ million per occurrence. Thus, it would be entitled to indemnification of up to $\$ 1$ million per claim. The insurer argued that there was but one underlying cause: the Red Cross' "general, negligent practice in handling HIV-contaminated blood."12 Under this view, the Red Cross would be entitled to a total indemnification, for all claims, only up to $\$ 1$ million.

A separate but related problem, the so-called "trigger-of-covcrage" issue, concerns when a CGL policy is activated. CGL policies provide coverage for injuries or damages that take place "during the policy period."13 Businesses often switch insurance companies from year to year. ${ }^{14}$ When damages span multiple policy periods, the insured and insurer once again have incentives to advance differing theories. The insured will argue for the theory that triggers the particular policy with the most favorable coverage, allowing for maximum indemnification. Each insurer in turn will argue for the theory that minimizes its liability, usually by triggering some other insurer's policy.

Two insurance cases involving asbestos manufacturers illustrate this dynamic. In Eagle-Picher Industries, Inc. v. Liberty Mutual Insurance Co., ${ }^{15}$ the insured, hit by a multitude of products liability suits stemming from its manufacture of asbestos-based products, argued that coverage under its insurance policy was not triggered until bodily injuries manifested themselves. Any other trigger would have devastated Eagle-Picher by leaving it without insurance, smce it had not purchased CGL coverage until just before injuries began to inamifest themselves. ${ }^{16}$ Eagle-Picher's insurer naturally argued for a pre-manifestation trigger, which would relieve it of the obligation to indemnify Eagle-Picher. ${ }^{17}$

10. American Red Cross v. Travelers Indem. Co., 816 F. Supp. 755,755 (D.D.C. 1993).

11. Id. at 760 .

12. Id. at 761 .

13. Aвraham, supra note 4 , at 440.

14. See, e.g., Chemstar, Inc. v. Liberty Mut. Ins. Co., 41 F.3d 429, 432 (9th Cir. 1994) (describing how the insured had purchased coverage over a number of years from four different insurers), petition for cert. filed, 63 U.S.L.W. 3599 (U.S. Feb. 6, 1995) (No. 94-1337).

15. 682 F.2d 12, 16 (1st Cir. 1982), cert. denied, 460 U.S. 1028 (1983).

16. See id. at 16-17.

17. Id. at $\mathrm{I} 6,19,23$. One of the insurers, Liberty Mutual, actually agreed with Eagle-Picher that the manifestation trigger applied. A second insurer-defendant, American Motorists, advanced the "premanifestation" theory to minimize its liability. Id. at 16. 
On the other hand, in Insurance Co. of North America v. Forty-Eight Insulations, Inc., ${ }^{18}$ it was the insurer that proposed a inanifestation trigger, while the insured argued that the exposure to asbestos-based products triggered indemnification liability. In that case, the manifestation trigger would have absolved the insurer of any liability. ${ }^{19}$

This Comnient focuses on the conflicting approaches taken in products liability cases where the inanifestation of dainage or injury is delayed, ${ }^{20}$ a source of frequent lawsuits. ${ }^{21}$ Because cases are constantly adopting different legal theories depending on the potential outcoines, the attempt to develop a coherent theory behind the definition of occurrence and the trigger-of-coverage issue is somewhat like the proverbial task of nailing jello to a wall. ${ }^{22}$

While these cases stem from different factual settings, and those differences might account for the existence of varying rules, such an explanation does not mean that variety is reasonable, tenable, or efficient. This

18. 633 F.2d 1212, 1222-23 (6th Cir. 1980), clarified on other grounds on reh' 'g, 657 F.2d 814 (6th Cir.), cert. denied, 454 U.S. 1109 (1981).

19. Moreover, a clause in the last insurer's CGL policy left the insured effectively without any coverage under the manifestation trigger. The last insurer had a $\$ 100,000$ deductible for asbestos cases. Most such cases settled for less than $\$ 100,000$. Id. at 1215 n.6.

20. Many of the earlier writings on these issues focused on situations involving asbestos-induced injuries. See, e.g., John P. Amess \& Randall D. Eliason, Insurance Coverage for "Property Damage" in Asbestos and Other Toxic Tort Cases, 72 VA. L. Rev. 943 (1986); Gail B. Agrawal, Comment, Asbestosis: Who Will Pay the Plaintiff?, 57 TuL. L. Rev. 1491 (1983); Rebecca C. Earnest, Recent Development, 58 WASH. L. Rev. 63 (1982) (discussing asbestosis in context of Keene Corp. v. Insurance Co. of N. Am., 667 F.2d 1034 (D.C. Cir. 1981)).

A later series of articles has focused on environmental damages. See, e.g., Kenneth S. Abraham, Environmental Liability and the Limits of Insurance, 88 CoLum. L. REv. 942 (1988); Eugenc R. Anderson et al., Liability Insurance Coverage for Pollution Claims, 59 Miss. L.J. 699 (1989); William R. Hickman \& Mary R. DeYoung, Allocation of Environmental Cleanup Liability Between Successive Insurers, 17 N. Ky. L. REv. 291 (1990); Frona M. Powell, Insuring Environmental Cleanup: Triggering Coverage for Environmental Property Damage Under the Terms of a Comprehensive General Liability Insurance Policy, 71 NeB. L. Rev. 1194 (1992); Jordan S. Stanzler \& Charles A. Yuen, Coverage for Environmental Cleanup Costs: History of the Word "Damages" in the Standard Form Comprehensive General Liability Policy, 1990 Colum. Bus. L. Rev. 449.

21. For example, manufacturer liability can arise from ingested medicines that lead to latent diseases or other internal injuries, commercial products that cause damages to buildings or other property, or toxic waste that seeps into the ground and takes several years to manifest as environmental damage. These situations are simply illustrative and not exhaustive of the sorts of problems that this Comment covers.

22. Insurers' duty to defend their insureds in litigation is much broader than the duty to indemnify. The duty to indemnify applies only when the insured is actually deemed liablc. On the other hand, the duty to defend, requiring insurers to pay for litigation costs relating to claims against the insured, attaches whenever a claim is filed, even if that claim is frivolous or groundless. See, e.g., Pacific Indem. Co. v. Linn, 590 F. Supp. 643, 646 (E.D. Pa. 1984), aff'd, 766 F.2d 754 (3d Cir. 1985); Gray v. Zurich Ins. Co., 419 P.2d 168 (Cal. 1966); Newell-Blais Post \#443, Veterans of Foreign Wars of the U.S., Inc. v. Shelby Mut. Ins. Co., 487 N.E.2d 1371, 1374 (Mass. 1986). Note, however, that even the duty to defend raises similar problems to those discussed in this Comment. See, e.g., TPLC, Inc. v. United Nat'l Ins. Co., 44 F.3d 1484, 1487-89 (10th Cir. 1995) (considering whether to spread litigation costs in a products liability suit among different insurance coverage periods). However, this Comment confines its attention to the duty to indemnify. 
Comment seeks to demonstrate that a single approach can in fact take into account factual differences while remainmg faithful to the CGL policy language. ${ }^{23}$ This Comment assumes that the insureds' CGL policies contain similar terms, even where the policy limits, deductibles, and potential exposure vary. ${ }^{24}$

Part I surveys the present legal landscape of the first problem, the definition of occurrence. Many courts reach the number of occurrences by determining the proximate cause of the damages or injuries. All damages or injuries stemming from what these courts consider to be the same underlying cause are treated as one occurrence. ${ }^{25}$ Other courts, however, take different approaches, usually by treating the number of claims as the number of occurrences. ${ }^{26}$ This Part argues for a umiform adoption of the majority position of ineasuring occurrences by determining the proximate cause of the injuries or damages.

Part II examines the second issue, the trigger-of-coverage problem. At present, there are four major theories for when CGL coverage is triggered: exposure to the damage-inducing product; manifestation of damage or injury; injury in fact; and continuous trigger. ${ }^{27}$ This Part argues that mjury in fact is the trigger theory most consistent with CGL policy language.

23. Two points are in order. First, many of the cases cited in this Comment are federal cases. Insurance law, however, belongs to the states. Under the McCarran-Ferguson Act, 15 U.S.C. §§ 1011 1015 (1992), Congress in the 1940s delegated regulation of insurance to the states. See also Prudential Ins. Co. v. Benjamin, 328 U.S. 408, 429-30 (1946) ("Congress' purpose was broadly to give support to the existing and future state systems for regulating and taxing the business of insurance. ... [1]ts purpose was evidently to throw the whole weight of its power behind the state systems . ..."). Thus, the cited federal cases, which are all based on diversity of citizenship, do not bind state courts, although they are often cited as persuasive authority. I selected these cases to provide a flavor of the law, not a comprehensive survey.

Second, many insurance disputes focus on what might be termed retroactivity. Even if courts across the nation adopted this Comment's proposal overnight, the problem of adjudicating disputes concerning the ambiguities of past policies would remain. Insurers that failed to anticipate this rule might not have charged appropriate premiums during past coverage periods. As a matter of equity and policy, however, it is not unreasonable to apply this Comment's rule to their policies. The insurers crcated their problems by drafting ambiguous policies. As a result, these ambiguities should be construed against them. See, e.g., Gaunt v. John Hancock Mut. Life Ins. Co., 160 F.2d 599, 602 (2d Cir.), cert. denied, 331 U.S. 849 (1947) ("[1]nsurers who seek to impose upon words of common speech an esoteric significance intelligible only to their craft, must bear the burden of any resulting confusion."). This principle is a specific application of the contract doctrine of contra proferentem, which construes ambiguities against contract drafters. E. Allan FARNSwORTH, Contracts $\$ 7.11$, at 499 (1982). Contra proferentem has applied even where the parties had equal bargaining strength. Id.

Additionally, the problem of retroactivity should not divert attention from the need to resolve the underlying problem: "to reflect now on what might have been done if the parties had contemplated today's problem is almost fatuous." Owens-Illinois, Inc. v. United Ins. Co., 650 A.2d 974, 992 (N.J. 1994).

24. Given the standardization in coverage terms, this assumption is not unreasonable. See Aвraham, supra note 4, at 28.

25. See infra part I.A.

26. See infra part I.B.

27. See infra part Il. 
Part III proposes a uniform approach for determining how many occurrences are involved in mass products liability lawsuits, which CGL policies are triggered, and how to allocate indemnification among multiple insurers. The goal of this approach is to remain faithful to the CGL policy language.

While a uniform approach may lack the flexibility needed to deal with extraordinary factual situations, ${ }^{28}$ adopting one approach for most insurance coverage disputes has several significant advantages. First, it will help avoid inconsistent outcomes, thereby providing predictability in the law. ${ }^{29}$ Second, it will reduce unnecessary litigation by establishing clear rules for how and when CGL coverage is triggered. ${ }^{30}$ Finally, it will help to restore faith in the legal systein as something more than a playing field for the games of wealthy corporations and insurance companies. ${ }^{31}$

Finally, Part IV justifies the proposed rule by reference to the CGL policy language, and through an economic analysis of the role of insurance and risk allocation. The use of probability theory illustrates the nature of the risk being transferred from insured to insurer and highlights why the suggested approach transfers that risk most efficiently.

28. See Arness \& Eliason, supra note 20, at 947-48.

Coverage questions cannot be decided in a factual vacuum. Asbestos in a building behaves very differently from, for example, toxic waste gradually leaking from barrels in a landfill onto adjoining property. Courts must recognize that no single rule can apply to all substances or even to all types of injuries from any one substance.

Id. Different factual settings do not necessarily require different rules, however. What they require is a rule that, taking into account meaningful differences, can arrive at different results. The injury-in-fact trigger, discussed infra part II.C and adopted as part of this Comment's uniform approach discussed at infra part II.E, should allay the concerns of Professors Amess and Eliason. In the examples they postulate, the injury-in-fact approach would trigger CGL policies in different ways based on the differing behavior of asbestos and toxic waste.

Of course, a crucial aspect of this Comment's proposal is the proration of liability where the factual inquiry concerning the time distribution of damages (that is, the year-by-year factual determination of damages) is virtually impossible to determine. See infra part III.A. The proposal allows insurers to prove that the damages associated with their coverage period were factually less than what the proposal apportions to them. See infra part IV.D.3.

29. See Abraham, supra note 20, at 957 (describing a loss of confidence in the ability to predict future legal outcomes); ABRAHAM, supra note 3, at 135 ("[C]ourts need to promulgate much clearer standards for resolving coordination disputes so that the insurance market can anticipate judicial action through pricing and sales practices."); Powell, supra note 20, at I224.

30. ABRAHAM, supra note 3, at I40 ("[S]ettling coordination questions in advance may bc more important than the particular rule that does the settling."); Powell, supra note 20, at 1224; see also Insurance Co. of N. Am. v. Forty-Eight Insulations, Inc., 633 F.2d 1212, 1218 (6th Cir. 1980), clarified on other grounds on reh' 'g, 657 F.2d 814 (6th Cir.), cert. denied, 454 U.S. 1109 (1981) ("The only thing on which all parties agree is that there is a need for us to arrive at an administratively manageable interpretation of the insurance policies-one that can be applied with minimal need for litigation."). A recent court noted that "[t]he present system is inefficient," with skyrocketing litigation costs. OwensIllinois, Inc. v. United Ins. Co., 650 A.2d 974, 993 (N.J. 1994).

31. See Arness \& Eliason, supra note 20 , at $944-45$ \& $n .8$. 
I

\section{Determining the NuMber of OCCURRENCES}

The typical CGL policy indemnifies an insured for payments it must make with respect to injuries or dainages that it causes and that result from an occurrence. ${ }^{32}$ In the 1960s, the Insurance Services Office ("ISO") switched to the term "occurrence" from "accident" to include the possibility of long-term causes of damage. ${ }^{33}$ The CGL, form does not state that the occurrence must take place during the time period covered by that insurer. ${ }^{34}$

The majority of federal and state courts define an occurrence as encompassing all injuries and damages stemming from the same cause. ${ }^{35} \mathrm{~A}$ minority of courts base the number of occurrences on the effect, which usually means the event triggering liability. ${ }^{36}$ However, neither position is solidified. For example, courts endorsing the majority view differ as to what constitutes the "cause" of injuries and damages.

\section{A. Majority Position: Underlying Cause}

A majority of courts apply the general proposition that an occurrence is tied to the underlying cause of damages. ${ }^{37}$ When it coines to defining the underlying cause of damages, however, the cases diverge. Soine courts define "cause" by looking to what they consider to be the proximate cause of the damages. Others consider the "cause" to be the basis of liability for the manufacturing entity.

\section{Causation View}

The "causation view" treats the proximate cause of the damages as the underlying cause, and therefore as the occurrence. ${ }^{38}$ Perhaps the inost com-

32. See, e.g., ABraham, supra note 4, at 440, 442-43.

33. Worcester Ins. Co. v. Fells Acres Day School, Inc., 558 N.E.2d 958, 973 (Mass. 1990) (citing Rosow \& Liederman, An Overview to the Interpretative Problems of "Occurrence" in Comprehensive General Liability Insurance, 16 FoRUM 1148,1149 (1981)). The 1 SO is a non-profit organization that, among other things, drafts standard form CGL policies for use by subscribing insurers. JERRY, supra note 5 , at $97 \mathrm{n.11}$. For a discussion of the advantages of standardized form policies, see Insurance Services Office, Inc., Insurance Services Office in a Competitive Marketplace: ISO's Role Within the Property Casualty Industry 6-7 (June 1987), reprinted in ABRAHAM, supra note 3, at 29-31.

34. The Abraham policy simply states that '[t]he 'bodily injury' or 'property damage' must be caused by an 'occurrence." " ABRAHAM, supra note 4, at 440.

35. See Michael P. Sullivan, Annotation, What Constitutes Single Accident or Occurrence Within Liability Policy Limiting Insurer's Liability to a Specified Amount Per Accident or Occurrence?, 64 A.L.R. 4th 668, 673 (1988); see also Hyer v. Inter-Insurance Exch. of the Auto. Club of So. Cal., 246 P. 1055 (Cal. Ct. App. 1926) (applying the causation view).

36. Sullivan, supra note 35 , at 673-74.

37. See, e.g., Appalachian lns. Co. v. Liberty Mut. Ins. Co., 676 F.2d 56, 61 (3d Cir. 1982); Champion Int'1 Corp. v. Continental Casualty Co., 546 F.2d 502, 505-06 (2d Cir. 1976), cert. denied, 434 U.S. 819 (1977).

38. Proximate cause is a term of art referring to "the limitation which the courts have placed upon the actor's responsibility for the consequences of the actor's conduct." W. PAGE KEETON, PROSSER AND KeEtON ON TORTS $\S 41$, at 264 (5th ed. 1984). Proximate cause is thus linked to cause-in-fact, but 
monly cited case for this proposition is Appalachian Insurance Co. $v$. Liberty Mutual Insurance Co. ${ }^{39}$ In this case, female employees filed a class-action lawsuit against Liberty Mutual, alleging that company policies discriminated on the basis of sex. Liberty Mutual had already ended the policies in question before purchasing insurance coverage from Appalachian. ${ }^{40}$ However, because it continued to pay out some settlement monies after Appalachian began coverage, Liberty Mutual wanted indemnification for these settlements. ${ }^{41}$ The Third Circuit, following the majority rule, affirmed the district court's finding that there had been one occurrence, because all the damages stemmed from the same discriminatory policies. ${ }^{42}$ That the injuries varied im magnitude and extended over a long period did not affect the result, so long as there was one proximate cause. ${ }^{43}$

A similar case involving products liability is Associated Indemnity Corp. v. Dow Chemical Co. ${ }^{44}$ Dow, through a subsidiary, produced a blended resin that was used in manufacturing gas pipelines. As the pipe developed leakage problems, it became clear that some of the resin "had excessive moisture and excessive foreign materials. Some . . . contained off-spec materials." 45 A Dow report concluded that even the best pipe made from the Dow resin could not be used in the rural program for which it had been intended. The report recommended replacing all pipe produced from this resin. ${ }^{46}$

The court set forth three guiding principles: (1) it would follow the majority causation rule; (2) "[a]11 property damage which results from one, proximate, uninterrupted, and continuing cause stems from a single occurrence"; and (3) "[i]f the continuous production and sale of an intrinsically harmful product results in similar kinds of property damage, then all such property damage results from a common occurrence." ${ }^{\$ 47}$ The court then identified the relevant damage as "[i]nstalled pipe that was replaced and discarded when repairs were made" and "[a]ll pipe in the ground when the

constrains liability to situations where the causal connection between the tortfeasor's action and the injury is reasonable. Id. at 263. For an extended discussion of proximate cause, see id. at $\$ \S 41-44$.

39. 676 F.2d 56 (3d Cir. 1982).

40. Id. at 58-59.

41. Id. at 59-60.

42. Id, at 61 . For a case where the discriminatory policies were race-based, rather than genderbased, see Transport Ins. Co. v. Lee Way Motor Freight, Inc., 487 F. Supp. 1325 (N.D. Tex. 1980).

43. Appalachian, 676 F.2d at 61; see also Mead Reinsurance v. Granite State Ins. Co., 873 F.2d 1185, 1187-88 (9th Cir. 1988) (finding that eleven instances of police brutality constituted one occurrence because the municipality allegedly had a policy of condoning use of excessive force by police); State Farm Fire \& Casualty Co. v. Elizabeth N., 12 Cal. Rptr. 2d 327, 329 (Ct. App. 1992) (holding that multiple instances of child molestation suffered at a child-care center constituted one occurrence, because the proximate cause of all the injuries was the center operator's negligence in Icaving the children with her husband, the molester).

44. 814 F. Supp. 613 (E.D. Mich. 1993).

45. Id. at 615 .

46. Id. at 615-16.

47. Id. at 621 . 
replacement programs were undertaken." ${ }^{\text {48 }}$ The damage included pipe that had yet to be removed because "[a]ll of the pipe had an unacceptable propensity to develop leaks after installation." 49

The court then determined that the cause of this property damage was that all of the resin sold by Dow's subsidiary was "intrinsically harmful because there was an unexplained property or characteristic of [the resin] such that all pipe extruded from it, by whatever method, was deficient for use in the rural gasification program." 50 While acknowledging that some of the resin may have been harmful due to production process flaws, the court maintained that there was only one occurrence, particularly because "it would be virtually impossible to sort out the damage, if any, which was solely attributable to other causes for which the insured was responsible."51

The court was not concerned that Dow's pipe had been installed in different weather conditions by different installers who used different techmques. ${ }^{52}$ It called the production of the defective resin the "overarching" as well as the "sole, proximate, uninterrupted, and continuing" cause of the property damage. ${ }^{53}$

A case similar to Dow is Chemstar, Inc. v. Liberty Mutual Insurance Co. ${ }^{54}$ The dispute in Chemstar involved defective lime used to make plaster for home use. The lime contained high amounts of periclase, a chemical

48. Id. at 622 .

49. Id.

50. Id. at 623 .

51. Id.

52. See id. at 615 (noting these differences without figuring them into decision).

53. Id. at 623. Various lower courts have also adopted the proximate causation view. In Air Prods. \& Chems., Inc. v. Hartford Accident \& Indem. Co., 707 F. Supp. 762 (E.D. Pa. 1989), rev'd on other grounds, Nos. 91-I681, 91-1682, 1994 U.S. App. LEXIS 12482 (3d Cir. May 31, I994), the plaintiff produced and sold welding products, and also owned a subsidiary that sold asbestos-based products. Numerous victims filed lawsuits against Air Products and its subsidiary, alleging injuries caused by exposure to gas and fumes from welding products and from asbestos products. Id. at 764 . The court, following the causation rule, held that there were two total occurrences, one stemming from the sale of welding products, and one from the sale of asbestos products. Id. at 773 . The court also examined the terms and language of the policy and concluded that the parties intended claims arising from the sale of a product to be a single occurrence. Id.

In Cargill, Inc. v. Liberty Mut. Ins. Co., 488 F. Supp. 49 (D. Minn. 1979), the court held that where a change in the formula of a biological growth medium damaged an antibiotic manufacturer, there was only one occurrence despite the production of numerous batches of the growth medium. The court looked to the underlying circumstances of the property damage, rather than the property damage itself. Id. at 53. It determined that the cbange in the formula caused the damage, and thus the change in formula was the occurrence. Id.

In Union Carbide Corp. v. Travelers Indem. Co., 399 F. Supp. 12 (W.D. Pa. 1975), the plaintiff sold defective chemicals to a manufacturer, resulting in multiple claims against the plaintiff. The court held that a single occurrence was involved when the plaintiff allowed a contaminant to remain in the chemical mix. Id. at 21 . The court's reasoning was based on three factors: (I) Union Carbide could have foreseen that a defect in the chemicals "would affect a large number of divers persons in the chain of distribution"; (2) considering each claim as an occurrence could lead to virtually limitless liability on the part of the insurer; and (3) earlier cases in other legal areas from a number of jurisdictions looked to the cause of the damages as being the occurrence. Id. at 17-20.

54. 41 F.3d 429 (9th Cir. 1994). 
compound that expands when exposed to water, including moisture in the air. $^{55}$ In twenty-eight homes, pits formed by the expanding periclase marred the original smooth plaster finish. ${ }^{56}$ The court noted that the periclase-tainted lime still could be used for outdoor purposes where pitting would not be noticed. ${ }^{57}$ Therefore, Chemstar could have avoided causing property damage by more carefully labelling such lime as being fit for outdoor-use only. ${ }^{58}$ Although the court did not use the term "proximate cause," it agreed with the district court that other possible explanations of the causes of pitting were irrelevant. ${ }^{59}$ None of the other suggested causes would have damaged the homes had Chemstar labelled the lime properly. ${ }^{60}$

Accordingly, the court held that the pitting of the plaster walls constituted a simgle occurrence, even though the lime used in those walls may have come from different batches. ${ }^{61}$ Because the language of the insurance policy was so broad-stating that "continuous or repeated exposure to substantially the same general conditions" constitutes one occurrence ${ }^{62}$ - the underlying cause, failure to warn, comprised the same general conditions that led to shipping the periclase-tainted lime for imdoor use. ${ }^{63}$

In each of these cases, the courts looked to the earliest proximate cause to determine the number of occurrences. In the case of mass products liability, the proximate cause of damage could be either a defective production process, or a corporate policy somehow encouraging or contributing to defective products, depending on the factual situation.

\section{Liability View}

Under the "liability view," courts still define occurrence based on the underlying cause of damages, but they focus on the basis for liability rather than the proximate cause of damages. ${ }^{64}$ In Michigan Chemical Corp. $v$. American Home Assurance Co., the appellant accidentally shipped flame retardant instead of livestock feed supplement to a third party. ${ }^{65}$ The third party mixed the flame retardant with regular livestock feed and sold the mixture to farmers. Some animals rejected the mixture; those cows that ate

55. Id. at 431.

56. Id.

57. Id.

58. Id.

59. As noted in the lower court opinion, these explanations included the use of one quarry, mere presence of periclase, hydration in the homes, and production defects. Chemstar, Inc. v. Liberty Mut. Ins. Co., 797 F. Supp. 1541, 1547 (C.D. Cal. 1992), aff'd, 41 F.3d 429 (9th Cir. 1994), petition for cert. filed, 63 U.S.L.W. 3599 (U.S. Feb. 6, 1995) (No. 94-1337).

60. Id.

61. See Chemstar, 41 F.3d at $432-33$.

62. The language of the policy is cited in the district court opinion. See Chentstar, 797 F. Supp. at 1548.

63. Chemstar, 41 F.3d at 433.

64. See, e.g., Michigan Chem. Corp. v. American Home Assurance Co., 728 F.2d 374 (6th Cir. 1984).

65. Id. at 376. 
it began producing less milk. ${ }^{66}$ As a result of the contamination, some 40,000 farm animals had to be killed. ${ }^{67}$ The court held that each inisshipment of flame retardant constituted a separate occurrence, because Michigan Chemical's liability resulted from each negligent misshipment: "Other shipments, if any took place, created additional exposure to liability and therefore were separate occurrences."

In applying the liability view, Michigan Chemical adopted a slightly more restrictive meaning of "underlying cause" than did Appalachian. If a inanufacturer made a defective batch of a product with multiple shipments, each shipment would constitute an occurrence under Michigan Chemical. Appalachian, on the other hand, would consider the making of the defective batch to be the occurrence. However, because this hypothetical case is based on a product defect claim, rather than negligence, as was the case in Michigan Chemical, some courts would find that, regardless of the number of batches, there was but one occurrence. In Household Manufacturing, Inc. v. Liberty Mutual Insurance Co., ${ }^{69}$ the court found that a series of claims against a plumbing system manufacturer was one occurrence, even though the claims alleged a variety of harms from the product's defect. Because these clains were for products liability, and "[t]he act which gives rise to plaintiff's liability . . . is [the] continuous and repeated sale of a defective product on a mass basis," there was only one occurrence. ${ }^{70}$ Thus, the divergence in underlying cause theories can perhaps be reconciled for mass products liability cases.

\section{B. Minority Position: Event as Liability}

A nuinber of courts either do not follow the majority rule, or interpret "underlying cause of damages" in a way that leads to the same result as under the minority "effect" and "liability trigger" rules.

\section{Effect View}

Under the "effect view," each injury is a separate occurrence. In Elston-Richards Storage Co. v. Indemnity Insurance Co. of North America, ${ }^{71}$ the plaintiff operated a storage facility. While insured by the defendant, the plaintiff negligently damaged over 4000 appliances by using
66. Id.
67. Id.
68. Id. at 383 .
69. No. 85 C 8519, 1987 U.S. Dist. LEXIS 1008, at *13-14 (N.D. 111. Feb. 10, 1987), vacated in part, 1987 U.S. Dist. LEXIS 10,837 (N.D. 11l. Nov. 16, 1987).

70. Id. at *12-13; see also Champion Int'1 Corp. v. Continental Casualty Co., 546 F.2d 502 (2d Cir. 1976), cert. denied, 434 U.S. 819 (1977).

71. 194 F. Supp. 673, 673 (W.D. Mich. 1960), aff'd per curiam, 291 F.2d 627 (6th Cir. 1961). 
a single defective inotorized lift. ${ }^{72}$ The court held that the danage to each appliance constituted a separate occurrence. ${ }^{73}$

Applied to a products liability situation with inultiple claims, ElstonRichards would mandate a finding of one occurrence per injured person or damaged piece of property. The force of Elston-Richards authority is questionable, however, when applied to the products liability context. Two connected federal products liability cases from the same state as ElstonRichards declined to follow the case. ${ }^{74}$ These cases, Dow I and Dow II, involved Sarabond, a product intended for use as a mortar adhesive. ${ }^{75}$ The use of Sarabond led to rust accumulations, eventually resulting in the visible cracking of the structure incorporating it. ${ }^{76}$ The court in Dow II rejected Elston-Richards for four reasons: "(1) the policy language is distinguishable; (2) Elston-Richards was not a products liability case; (3) it did not involve claims by multiple parties; (4) it was decided before the trend of modern cases which favors the view that the [occurrence] clause refers to the cause or causes of the accident or occurrence."177

\section{Liability-Trigger View}

The "liability-trigger view" resembles, to some degree, the basis for liability rule applied in Michigan Chemical. However, the minority version of the rule looks at the liability from the point of view of the victims, so that each act giving rise to liability to different victims constitutes a separate occurrence. The leading proponent of this view is Maurice Pincoffs Co. $v$. St. Paul Fire \& Marine Insurance Co. ${ }^{78}$

In Pincoffs, the plaintiff imported birdseed that turned out to be contaminated with a lethal toxin. ${ }^{79}$ During a nine-day period, the plaintiff made eight separate sales of the contaminated birdseed, resulting in numerous bird deaths. As a result, the bird owners filed suit. ${ }^{80}$ The court looked to the language of the policy ${ }^{81}$ and held that "occurrence" meant the "occurrence of the events or incidents for which Pincoffs is liable. It was the sale of the contaminated seed for which Pincoffs was liable." ${ }^{\text {22 }}$ Thus, each sale

72. Id. at $673-74,677$.

73. Id. at 682.

74. See Dow Chem. Co. v. Associated Indem. Corp., 727 F. Supp. 1524, 1528 (E.D. Mich. 1989) ("Dow II'). Dow Chem. Co. v. Associated Indem. Corp., 724 F. Supp. 474 (E.D. Mich. 1989) ("Dow $\left.\Gamma^{\prime \prime}\right)$, involved the same complaint but dealt with the trigger-of-coverage issuc.

75. Dow I, 724 F. Supp. at 476; Dow II, 727 F. Supp. at 1525.

76. Dow I, 724 F. Supp. at 477.

77. Dow II, 727 F. Supp. at I528. Eventually, the court did find that there were multiple occurrenccs. Id. at 153I-32. That aspect of the case is discussed later in this Comment.

78. 447 F.2d 204 (5th Cir. 1971).

79. Id. at 205.

80. Id.

81. The exact language read: "' 'Occurrence' means an accident, including injurious cxposure to conditions, which results, during the policy period, in bodily injury or property damage neither expected nor intended from the standpoint of the insured." Id. at 206.

82. Id. 
counted as a separate occurrence. The court reasoned that each sale exposed a victim to property damage. ${ }^{83}$

Another case adhering to the liability-trigger view is Mason v. Home Insurance Co. ${ }^{84}$ The policy language in Mason was substantially similar to that in Pincoffs. ${ }^{85}$ Over three days, numerous patrons of a local restaurant insured by the defendant suffered botulism poisoning. ${ }^{86}$ The court held that each sale of tainted food was a separate occurrence because "[s]o long as the Skewer Inn retained possession of the tainted food, no liability could result. Serving to a consumer a food item contaminated with the botulism toxin constituted the act from which liability arose."87 Thus, each additional sale created additional liability, and therefore counted as a separate occurrence. $^{88}$

Like Pincoffs, Mason illustrates an approach to viewing the liabilitytriggering event that differs from that used in Michigan Chemical. The Michigan Chemical court would probably hold that there was only one occurrence in each of these cases, as it was the general act of selling, and not the individual sales, that exposed the companies to liability.

Those cases that have defined occurrence as the policy language indicates - from the point of view of the insured, rather than the victims - have used a proximate-cause approach. ${ }^{89}$ A careful analysis of Mason reveals that it is similar to the majority rule, yet misreads key elements of cases propounding that rule.

In Mason the court analogized its reasoning to that in Michigan Chemical. ${ }^{90}$ The Mason court, however, missed the fact that the cause of action in Michigan Chemical was the negligent misshipment of flame retardant. This distinction is important, because flame retardant, by itself, is not a defective product. The problem arose because Michigan Chemical sent out the flame retardant for an improper use. Unless Michigan Chemical had a policy of misshipping (something analogous to the policy of discriminating against women in Appalachian), each negligent act of misshipping was itself the underlying cause of injury. Botulism-tainted food, on the other hand, has no use, and therefore is clearly a defective product. Thus, in Mason, the occurrence should have been defined by the

83. Id.

84. 532 N.E.2d 526, 529 (Ill. App. Ct. 1988).

85. The exact terms included a statement that "[a]ll damages arising out of such exposure to substantially the same general conditions shall be considered as arising out of one occurrence." Id. at 527.

86. Id.

87. Id. at 529.

88. Id.

89. See, e.g., Appalachian Ins. Co. v. Liberty Mut. Ins. Co., 676 F.2d 56 (3d Cir. 1982); Champion Int'l Corp. v. Continental Casualty Co., 546 F.2d 502 (2d Cir. 1976), cert. denied, 434 U.S. 819 (1977).

90. Mason, 532 N.E.2d at $529-30$. 
proximate cause, which was whatever caused the food to be tainted by botulism.

Thus, the essential difference between the majority approach of Michigan Chemical and Dow on the one hand, and the minority approach of Mason and Pincoffs on the other, is that the former defines proximate cause as the earliest opportunity that the insured could have averted disaster, while the latter defines it as the event by which disaster strikes the victims. In Michigan Chemical, the flame retardant was not inherently defective; thus, the earliest opportunity that Michigan Chemical had to avoid calamity was to refrain from misshipping it as livestock fced supplement. In Dow, the use of defective resin led to defective pipe. Dow could have avoided causing damage by not shipping the defective pipe; however, Dow had an earlier opportunity to prevent harm by not using defective resin. The court accordingly found the occurrence to be Dow's use of defective resin. In contrast, in Pincoffs, the court viewed each sale of the tainted birdseed as "causing" the damage, even though the court realized that "[i]f Pincoffs had destroyed the seed before sale . . . there would be no occurrence at all."91

\section{Choosing a Rule for Determining the Number of Occurrences}

This Comment advocates the majority position of treating the proximate cause of injury or damages, as seen from the point of view of the insured rather than that of the victims, as the occurrence to be covered by the CGL policy. ${ }^{92}$ The expectations of the insured based on the CGL policy language and the historical context of the drafting of the terms point toward such a proximate-cause analysis. In addition, treating the earliest proximate cause of injury or damages as the occurrence will help reduce repetitious and unnecessary litigation; this position finds analogous support in the joinder rules of the Federal Rules of Civil Procedure. ${ }^{93}$

\section{Expectations of the Insured}

Beginning in the 1960 s, courts adjudicating coverage disputes routinely construed insurance policies to provide the insured with its reasonable expectation of coverage, even if that expectation was not reflected in the language of the policy. ${ }^{94}$ In general, this doctrine has served to protect

91. Pincoffs, 447 F.2d at 206.

92. Of course, the primary goal is to settle on one method for determining the number of occurrences. Therefore, even if courts choose not to adopt the proximate-cause approach, they should choose some other occurrence analysis to be applied uniformly. See supra notes $29-31$ and accompanying text.

93. See infra notes 101-104 and accompanying text.

94. ABRAHAM, supra note 3, at 103; JERRY, supra note 5, at 106-07. In 1970, Professor Keeton summarized the state of the law in an often-cited article: "The objectively reasonable expectations of applicants and intended beneficiaries regarding the terms of insurance contracts will be honored even 
"ordinary consumers without a sophisticated understanding of insurance." 95 Notwithstanding the fact that businesses are not ordinary consumers, the meaning of the term "occurrence" is susceptible to this doctrine if "the insured could reasonably have expected coverage largely because the insurer's words, conduct, or a situation for which the insurer is responsible have created that expectation." 96

There are two reasons an insured manufacturer might expect the "occurrence" to be defined by the earliest proximate cause of damages, rather than the damages themselves. First, the 1966 version of the standard CGL policy, which used the term "accident" instead of "occurrence," determined whether an accident took place from the point of view of the insured. ${ }^{97}$ The ISO had specifically revised the language to make this interpretation clear so that coverage under the 1966 version would be narrower. Previously, "[v]iewing the incident from the viewpoint of the victim would almost always lead to a conclusion that the loss in question was an accident and therefore covered, since victims rarely foresee, imtend, or expect the loss caused by the insured." 98

Given that insurers had clarified this viewpoint-oriented approach with respect to the definition of "accident," an insured could reasonably expect that the same approach would apply to "occurrence," in the absence of any explicit language to the contrary. ${ }^{99}$ Viewing the incident from the perspective of the insured, as opposed to the victim, allows the proximate-cause analysis to take a step back to the earliest opportunity the insured had to avoid causing injury or damage.

Another reason that manufacturing insureds could reasonably expect the number of occurrences to be determined from the proximate cause is the existence of "claims made" policies, which provide CGL coverage "on the basis of mdividual accidents giving rise to claims." 100 Defining the "occur-

though painstaking study of the policy provisions would have negated those expectations." Robert $\mathrm{E}$. Keeton, Insurance Law Rights at Variance with Policy Provisions, 83 HaRv. L. Rev. 961,967 (1970).

95. Aвraham, supra note 3, at 103.

96. Id. at 104.

97. JERRY, supra note 5, at 334 .

98. Id.

99. Fulfilling such an expectation is not only reasonable but consistent with the doctrine of contra proferentem, which construes ambiguities against contract drafters. For a lengthier discussion, see supra note 23.

100. Champion Int'l Corp. v. Continental Casualty Co., 546 F.2d 502, 505-06 (2d Cir. 1976) (indicating that such policies exist by noting Champion's failure to choose one). The difference between the types of policies has been described as follows: "claims made" policies "provide unlimited retroactive coverage and no prospective coverage at all," while "occurrence" policies "provide unlimited prospective coverage and no retroactive coverage at all." Brander v. Nabors, 443 F. Supp. 764, 767 (N.D. Miss.), aff 'd, 579 F.2d 888 (5th Cir. 1978). For an extended discussion of the difference between "per occurrence" and "per claim" insurance policies, see Bay Cities Paving \& Grading, Inc. v. Lawyers" Mut. Ins. Co., 855 P.2d 1263, 1265-70 (Cal. I993); Pacific Employers Ins. Co. v. Superior Court, 270 Cal. Rptr. 779, 784-86 (Ct. App. 1990); Aвraham, supra note 3, at 49-51; Sol Kroll, The Professional Liability Policy "Claims Made," 13 Forum 842, 843 (1978); Richard C. Tinney, Annotation, Event as 
rence" by damages instead of by proximate cause essentially converts standard CGL policies into "claims made" policies. An insured's selection of a "per occurrence" rather than a "per clain" policy should suggest that it wants coverage to be measured by the underlying circuinstances that result in the clain for damages: the proximate cause. Thus, the proximate-cause test for defining occurrences best represents the reasonable expectations of the insured.

\section{Reducing Duplicative Litigation}

Adopting the proximate-cause method for determining the number of occurrences will also reduce duplicative and unnecessary litigation between insureds and insurers by consolidating fact-finding. This test finds support in the analogous situation of determining when parties can be joined permissively under the Federal Rules of Civil Procedure. The nnderlying rationale of the joinder rules is that joint trials reduce the costs of litigation and the burden on the court system. ${ }^{101}$ Rule 20(a) of the Federal Rules of Civil Procedure states in relevant part:

All persons may join in one action as plaintiffs if they assert any right to relief ... in respect of or arising out of the same transaction, occurrence, or series of transactions or occurrences and if any question of law or fact common to all these persons will arise in the action. $^{102}$

The first of Rule 20's two requirements is applicable to an analysis of the underlying cause of dainages: the requireinent of "the same transaction, occurrence, or series of transactions or occurrences." 103 At least one court has interpreted this requirement to inean that "all reasonably related clains for relief by or against different parties [can] be tried in a single proceeding. Absolute identity of all events is unnecessary." ucts liability coverage dispute mirrors the Rule 20 interpretation. However, the event in question in a products liability situation-the occurrenceallows a series of plaintiffs to institute actions against the defendant inanufacturer, rather than allowing the manufacturer to institute actions against others.

Occurring Within Period of Coverage of "Occurrence" and "Discovery" or "Claims Made" Liability Policies, 37 A.L.R.4th 382, 390-92 (1985).

101. See, e.g., Stanford v. Tennessee Valley Auth., 18 F.R.D. 152, 155 (M.D. Tenn. 1955); Note, Class Certification in Mass Accident Cases Under Rule 23(b)(1), 96 HARv. L. Rev. 1143, 1144-48 (1983). Recognizing these bcnefits, the United States Supreme Court has encouraged joinder of parties. See United Mine Workers v. Gibbs, 383 U.S. 715, 724 (1966).

102. FED. R. Crv. P. 20(a); see also MrCH. CT. R. 2.206(A) (allowing joinder of parties where the right arises "out of the same transaetion, occurrence, or series of transactions or occurrences"); N.Y. Civ. Prac. L. \& R. 1002 (same).

103. Fed. R. Civ. P. 20(a).

104. Mosley v. General Motors Corp., 497 F.2d 1330, 1333 (8th Cir. 1974). 
This principle therefore applies only by analogy, since the controversy in a products liability coverage dispute is between the insurer and the insured, and not between the insured manufacturer and the victims. Nevertheless, treating the proximate cause of products liability damages as the occurrence is consistent with the Federal Rules' emphasis on avoiding duplicative litigation. By determining the number of occurrences this way, a court resolving a coverage dispute may be able to combine into one proceeding all inquiries as to which policies a given occurrence triggers rather than having to do so piecenreal over a number of suits. The fact that the focus is on indemnification indicates that the manufacturer's liability, and hence the causal connection between the occurrence and the damages, has already been established. One proceeding has the advantage of collecting all the insurers together so that expert testimony and evidence concerning the occurrence can be presented at one time, to avoid repetition of the same factual issues. ${ }^{105}$ Conversely, treating each claim as an occurrence necessitates separate inquiries into which policy each occurrence falls under, and whether each occurrence qualifies for coverage. ${ }^{106}$

One apparent solution might be to use issue preclusion to avoid the need for multiple proceedings. Issue preclusion, or collateral estoppel, bars a party from relitigating issues that were actually decided in a previous adjudication. ${ }^{107}$ Insurers might argue, for example, that once the insured loses with regard to whether a claim agamst it is covered by the insurer as an occurrence, that judgment should bind it with respect to all other claims. The United States Supreme Court has endorsed this kind of issue preclusion, known as "offensive collateral estoppel."108 However, the Court acknowledged the potential for abuse of offensive collateral estoppel, particularly in mass torts, by citing a law professor's famous example:

[A] railroad collision injures 50 passengers all of whom bring separate actions against the railroad. After the railroad wins the first 25 suits, a plaintiff wins in suit 26. Professor Currie argues that offensive use of collateral estoppel should not be applied so as to allow plaintiffs 27 through 50 automatically to recover. ${ }^{109}$

Some courts have responded to Professor Currie's argument by refusing to apply collateral estoppel offensively where inconsistent verdicts may

105. For an example of a district court judge's unfavorable opinion of potentially repeated and redundant testimony, see Jenkins v. Raymark Indus., Inc., 782 F.2d 468, 473 (5th Cir. 1986).

106. See infra part II.

107. See Restatement (Second) of Judgments $\S 27$ (1982); Jack H. Friedenthal ex al., Civil Procedure § 14.9, at 659-60 (2d ed. 1993).

108. See Parklane Hosiery Co. v. Shore, 439 U.S. 322 (1979) (holding that offensive collateral estoppel is permissible as long as certain conditions are met).

I09. Id. at 330-31 n.14 (citing Brainerd Currie, Mutuality of Estoppel: Limits of the Bernhard Doctrine, 9 Stan. L. Rev. 281, 304 (1957)). 
result. ${ }^{110}$ The situation where a court is trying to determine whether a single claim constitutes an occurrence is precisely the situation that Professor Currie foresaw: an msured could win the issue for the first few coverage dispute suits and then lose one, and be bound with respect to the remaining claims.

In summary, adopting a uniform rule of determining the number of occurrences by the proximate cause, from the point of view of the insured, provides a reasonably clear definition for courts to use: the earliest opportunity the insured had to avoid causing the multiple injuries or damages. This approach comports with the purpose of the ISO in switching to the term "occurrence" from "accident," and will also help to reduce duplicative litigation.

\section{II}

\section{TRIGgER OF COVERAGE}

While the occurrence issue determines how much indemnification an insurer must provide, the trigger-of-coverage issue focuses on when damage or injury occurs for the purpose of determining which insurance policy is liable for indemnification. The typical CGL policy provides indemnification 'to 'bodily injury' and 'property damage' which occurs during the policy period."111 Products liability actions, which can involve injuries or damages with delayed nranifestation, possibly spanning a number of years and therefore multiple insurance policies, pose a difficult problem that traditional CGL policies are ill-equipped to solve. ${ }^{112}$ There are four generally accepted methods of determining when insurance coverage is triggered: (1) the time of manifestation of damage; (2) the time of exposure to the injury-causing agent; (3) continuous trigger from the time of exposure through the time of nianifestation (also known as "multiple trigger"); and (4) the time of so-called "injury in fact."113 This section reviews each of these trigger theories.

110. See, e.g., Hardy v. Johns-Manville Sales Corp., 681 F.2d 334, 345-46 (5th Cir. 1982) (holding that one reason to deny the use of offensive collateral estoppel is the "presence of inconsistent verdicts').

111. Abratiam, supra note 4 , at 440 .

112. See Insurance Co. of N. Am. v. Forty-Eight Insulations, Inc., 633 F.2d 1212 (6th Cir. 1980), clarified on other grounds on reh'g, 657 F.2d 814 (6th Cir.), cert. denied, 454 U.S. 1109 (1981).

113. Kenneth S. Abraham, Environmental Liability Insurance Law: An Analysis of Toxic Tort and Hazardous Waste Insurance Coverage Issues 96 (1991); Martin J. McMahon, Annotation, Event Triggering Liability Insurance Coverage as Occurring Within Period of Time Covered by Liability Insurance Policy Where Injury or Damage Is Delayed-Modern Cases, 14 A.L.R.5th 695, 722 (1993). The exposure trigger is favored by Idaho and Vermont. Id. at 724-25. The manifestation trigger is favored by Alabama, Ohio, Texas, North Carolina, Louisiana, and South Carolina. The continuous trigger is favored by Connecticut, New Jersey, and Wisconsin. Id. at 727-28. The injury-in-fact trigger is favored by Missouri, North Dakota, Oklahoma, Washington, Georgia, and Massachusetts. A number of states have not adopted a consistent rule: Pennsylvania, New York, Minnesota, Indiana, California, Itlinois, and Michigan. See id. at 724-44. 


\section{A. Manifestation of Damages or Injuries}

Under the "manifestation" theory, coverage is triggered when the damage becomes known to the victim or property owner. One early case advocating the mamifestation rule was Eagle-Picher Industries, Inc. v. Liberty Mutual Insurance Co. ${ }^{114}$ Eagle-Picher argued for the manifestation theory because prior to 1968 , it had no liability insurance. ${ }^{115}$ Lawsuits filed against Eagle-Picher alleging injury caused by asbestos exposure began in the mid-1960s and continued through the early 1980s. ${ }^{16}$ The court first held that a manifestation trigger was inore in line with the policy language than was the exposure theory. ${ }^{117}$ The policy, which contained language resembling standard policy language, had two components: exposure and injury. The court determined that manifestation of the injury must occur within the policy period for indemnification to be required. ${ }^{118}$ The court then concluded that the lung-tissue damage caused by the initial exposure to asbestos did not qualify as the manifestation of injury. ${ }^{119}$

A recent products liability case subscribing to this theory is Chemstar, Inc. v. Liberty Mutual Insurance Co. ${ }^{120}$ Chemstar manufactured plaster that turned out to be unsuitable for indoor use, because when used indoors it caused cosmetic damage. ${ }^{121}$ The owners of the twenty-eight damaged homes filed claims between 1985 and 1988. ${ }^{122}$ The court adopted the manifestation trigger primarily because it (1) promoted greater certainty for the insurer and imsured ${ }^{123}$ and (2) would "affect only the allocation of coverage among insurers," with no impact on the insured. ${ }^{124}$

\section{Benefits of the Manifestation Trigger}

Under the manifestation theory, CGL coverage is triggered when damage caused by the insured's products or services "manifests" itself. In general, insurers prefer the manifestation trigger, as their liability is easier to

114. 682 F.2d 12, 15-16 (1st Cir. 1982), cert. denied, 460 U.S. 1028 (1983).

115. Id. at 16.

116. Id. at 15 .

117. Id. at 19. For a discussion of the exposure trigger, see infra part II.B.

118. Eagle-Picher, 682 F.2d at 19.

119. Id. In a remarkably imperceptive comment, the court noted that "[a]n individual with tiny sub-clinical insults to her lungs would not say that she had any injury or disease, given one expert's testimony that "over $90 \%$ of all urban city dwellers have asbestos-related scarring.' " Id. The fact that $90 \%$ of city dwcllers have asbestos-caused damage does not mean that one who had heen exposed to asbestos would not think that the additional sub-clinical insults were not manifested damage, simply hecause one already had some.

120. 41 F.3d 429 (9th Cir. 1994).

121. Id. at 431 .

122. Id.

123. Id. at 435 .

124. Id. 
determine when that trigger is used. ${ }^{125}$ Courts have endorsed the manifestation-trigger theory on this basis. In Prudential-LMI Commercial Insurance v. Superior Court, ${ }^{126}$ the California Supreme Court stated that the manifestation theory would "promote[] certainty in the insurance industry and allow[] insurers to gauge premiums with greater accuracy." Greater certainty, in turn, enables insurers to charge more accurate premiums. ${ }^{127}$ The court in Chemstar posited that, under a manifestation trigger, insurers can rest assured that once their policies expire they will not be liable for damage that may have festered unseen while they were providing covcrage. ${ }^{128}$

\section{Why the Manifestation Trigger Should Be Abandoned}

Other courts and commentators have argued that the manifestation theory actually leads to reduced insurance coverage, because insurers may refuse to write new policies once it becomes "apparent that the period of manifestations, and hence a flood of claims, [is] approaching."129 This practice is known as the "cut-and-run" problem. The drafting history of the CGL form suggests that the drafters were concerned about this problem, along with the fact that "injuries sufficiently serious to trigger coverage could occur prior to any form of manifestation."130

A substantial problein with the mamifestation theory is that it runs contrary to the language of CGL policies, which cover damage that "occurs during the policy period."131 For the manifestation trigger to be faithful to this language, the manifestation of damage must take place at the same time as the damage itself. By hypothesis, however, this Comment focuses on

125. David J. Dykhouse \& Joseph L. Falik, Trigger of Coverage: The Business Context, the Plain Language, and American Home Products, 16 CoNN. L. REv. 497, 498 (1984); John D. Ingram, Insurance Coverage Problems in Latent Disease and Injury Cases, 12 ENvTL. L. 317, 336 (1982).

126. 798 P.2d 1230, 1246 (Cal. 1990) (citation omitted).

127. Id. More accurate premiums may result from the manifestation trigger for several reasons:

First, it keeps the bulk of incurred loss recorded on more recent dates than would be the case if Iosses were recorded as of the date of injury in fact. This means, in turn, that estimates of such losses can be more readily reflected in future rates for a more accurate price than if such losses were recorded as scattered over a wide past period. Second, such massing of losses in relatively recent past periods facilitates the application of the techniques of actuarial science to the measuring of the adequacy of loss reserves .... Third, such a date is more easily aseertainable by the clerical personnel that insurers employ in this phase of claim processing. ... Finally, by pushing loss dates forward in this fashion, insurers give themselves more future time during which to accumulate the necessary Ioss paying funds.

Dykhouse \& Falik, supra note 125 , at 501.

128. Chemstar, 4I F.3d at 435.

129. Developments in the Law-Toxic Waste Litigation, 99 HARv. L. REv. 1458, 1580 (1986); see also Hancock Lab., Inc. v. Admiral Ins. Co., 777 F.2d 520, 525 (9th Cir. 1985) (acknowledging this problem and rejecting the manifestation trigger); ABRAHAM, supra note 113, at 103 ("Thus, adoption of a manifestation trigger risks the complete elimination of future coverage arising out of risks already taken at the time this trigger theory is adopted.").

130. See American Home Prods. Corp. v. Liberty Mut. Ins. Co., 565 F. Supp. 1485, 1501-02 (S.D.N.Y. 1983), aff' $d$ and modified, 748 F.2d 760 (2d Cir. 1984) (discussing drafting history of CGL).

131. See, e.g., TBG, Inc. v. Commercial Union Ins. Co., 806 F. Supp. 1444, 1453 (N.D. Cal. 1990); Lee H. Ogburn, The Progression of Trigger Litigation in Maryland-Determining the Appropriate Trigger of Coverage, Its Limitations, and Ramifications, 53 MD. L. REv. 220, 229 (1994). 
situations with delayed manifestation, where manifestation and damages do not occur simultaneously. ${ }^{132}$ The policy language indicates that CGL policy covers damage occurring during the coverage period, not manifestation of damage. Although manifestation of damage would be a strained definition of damage, ${ }^{133}$ insurers could, if they so desired, include language to this effect in the standard form definitions of their CGL policies. In the absence of such a definition, however, inamifestation of dainage and the actual infliction of damage are naturally considered separate events. ${ }^{134}$

In some ways, the recent proliferation of so-called "pollution exclusion" clauses in CGL policies underscores the "cut-and-run" problem of the inanifestation trigger. The 1986 version of the CGL policy excludes coverage for " '[b]odily injury' or 'property damage' arising out of the actual, alleged or threatened discharge, dispersal, release or escape of pollutants ... [and for] [a]ny loss, cost, or expense arising out of any governmental direction or request that you test for, nonitor, clean up, remove, contain, treat, detoxify or neutralize pollutants."135

By 1986, insurers no doubt saw that their potential liability for environmental dainages caused by their insureds was skyrocketing. If the mamfestation trigger were used, the policy in place at the time of an injury's manifestation would govern. Under the manifestation theory, starting in 1986, insurers' liability for pollution caused by the insured even before 1986 is removed. Conversely, use of the exposure, injury-in-fact, or continuous triggers would inean application of whatever insurance policy was in place at the time of exposure, injury in fact, or both. Thus, insurers' atteinpts to reduce liability on pre-1986 policies through insertion of pollution-exclusion clauses are unavailing under these triggers.

Thus, to allow the manifestation trigger to apply the pollution exclusion retroactively in this manner is, from the standpoint of an imsured, unexpected and inequitable. The premiums paid by the insureds during the years before the existence of pollution-exclusion clauses reflected the insureds' expectations that their CGL policies would cover the risk of environmental

132. The situation where manifestation occurs simultaneously with damage is not intellectually challenging, as all differences between the various trigger theories collapse, since all yield the same result.

133. "Damage" is defined as "injury ... . resulting in a loss in soundness, value, etc." WeBSTER's New World Dictionary of the American Language 356 (David B. Guralnik ed., 2d college ed. 1979). "Injury" is defined as "physical harm or damage to a person, property, etc." Id. at 725. "Manifest," as a verb, is defined as "to make clear or evident; show plainly; revcal; evince." Id. at 86I.

I34. A simple analogy illustratcs the difference. Consider a football player who suffers a broken toe during the first quarter, but continues to play the entire game. From the television replay, one can determine the exact play in which the player was injured. However, due to his competitive spirit and adrenaline, the player does not feel the pain until after the game is over. Under the manifestation trigger, the "damage" does not occur until after the game, because that is when the player notices that he has been hurt. Yet, the only meaningful time to which the injury can be linked is a specific play in the first quarter. If the manifestation-trigger theory were nsed and the insurance policy expired immediately after the game ended, the player's injury would not be covered.

I35. ABRAHaM, supra note 4 , at $44 \mathrm{I}$. 
damage. ${ }^{136}$ Thus, the msurers would be unjustly enriched if the manifestation trigger allowed them to apply the pollution exclusion for acts that occurred before 1986.

Courts that reject the manifestation trigger often do so on the grounds that it converts "occurrence" policies into "claims made" policies, and thus violates the intentions of the parties. ${ }^{137}$ A claims-made policy will generally result in lower premiums because the insurer can predict its exposure and establish its reserves more accurately than under an "occurrence" policy. ${ }^{138}$ The fact that claims-made policies may result in lower premiums does not imply, however, that courts should turn occurrence policies into claims-made policies. For one thing, the insured has already paid higher premiums for the occurrence policy. Thus, the insured would be receiving less coverage for a higher price. Moreover, if the insured had wanted to be covered on a claims-made basis, it could have purchased a claims-made policy. The fact that it did not should imdicate its preference not to be covered as if under a claims-made policy.

Finally, the major third-party insurance case adopting the manifestation trigger, Eagle-Picher, has been criticized as being result-oriented. ${ }^{139}$ In fact, the Eagle-Picher court itself seemed to acknowledge as much, stating that it would resolve any remaining doubts in favor of the insured, so as to provide maximum coverage. ${ }^{140}$ It is ironic that Eagle-Picher is now used to justify decisions that favor insurers at the expense of insureds.

\section{B. Exposure to Defective Product}

\section{Application of the Exposure Trigger}

Under the "exposure" theory, CGL coverage is triggered when the victim is first exposed to the cause or source of injury. One of the earliest cases to promote this theory was Insurance Co. of North America $v$. Forty-Eight Insulations, Inc. ${ }^{141}$ In Forty-Eight Insulations, a manufacturer mcurred massive liability due to a host of products liability clainis alleging asbestos-related injuries. ${ }^{142}$ The court found that exposure, not manifesta-

136. For a discussion of premium calculations, sce infra note 270 and accompanying text.

137. See, e.g., Trizec Properties, Inc. v. Biltmore Constr. Co., 767 F.2d 810, 812-13 \& n.6 (11th Cir. 1985).

138. Montrose Chem. Corp. v. Admiral Ins. Co., 5 Cal. Rptr. 2d 358, 368 (Ct. App. 1992), aff'd, 897 P.2d 1 (Cal. 1995); Gerald Kroll, Comment, The "Claims Made" Dilemma in Professional Liability Insurance, 22 UCLA L. REv. 925, 928 (1975).

139. See, e.g., Armstrong World Indus., Inc. v. Actna Casuaity \& Sur. Co., 26 Cal. Rptr. 2d 35, 5 I (Ct. App. 1993) (calling Eagle-Picher an aberration), rev. granted sub nom. In re Asbestos Ins. Coverage Cases, 866 P.2d 1311 (Cal. 1994), transferred by, 904 P.2d 370 (Cal. 1995).

140. Eagle-Picher Indus., Inc., v. Liberty Mut. Ins. Co., 682 F.2d 12, 23 (1st Cir. 1982), cert. denied, 460 U.S. 1028 (1983).

141. 633 F.2d 1212 (6th Cir. 1980), clarified on other grounds on reh'g, 657 F.2d 814 (6th Cir.), cert. denied, 454 U.S. 1109 (1981).

142. Id. at 1215 . 
tion, was the appropriate trigger of coverage. ${ }^{143}$ Medical testimony strongly supported the exposure theory because every inhalation of asbestos fibers caused lung-tissue damage, and tissue damage is bodily injury. ${ }^{144}$

The court rejected the mamifestation theory for three reasons. First, the manifestation trigger produced CGL coverage that did not match the underlying asbestosis claims. Thus, it would defeat the expectations of the insured, who would expect coverage to parallel the nature of the claims. ${ }^{145}$ Second, the court found that the medical community agreed that "the time when asbestosis mamifests itself is not the time when the disease occur[s]." ${ }^{146}$ Finally, the court followed the general principle of construing insurance policies broadly to provide coverage. ${ }^{147}$

Relying on Forty-Eight Insulations, the court in Hancock Laboratories, Inc. v. Admiral Insurance Co., ${ }^{148}$ applied the exposure theory to the implantation of a defective heart valve. Hancock manufactured a "porcine aortic heart valve" for use as a replacement valve in human hearts. ${ }^{149}$ One of the valves turned out to be contaminated with microbacteria, necessitating the removal of the valve and the implantation of a new valve. ${ }^{150}$ When the person who received the defective valve sued Hancock, Hancock's insurer refused to defend the suit on the grounds that the old valve was removed after the policy had expired. ${ }^{151}$

The Ninth Circuit rejected the mamifestation and continuous-exposure theories, and adopted exposure as the trigger. ${ }^{152}$ The court found that the defective heart valve created a cumulative, progressive disease analogous to abestosis in that, "following exposure to the contaminated valve, the [disease-causing] bacteria continued to grow."153 The court then noted that exposure to the damaging products, whether asbestos fibers or a defective heart valve, starts the progressive disease process. ${ }^{154}$ Unlike asbestos cases, however, in which there are typically multiple inhalations of asbestos fibers

143. Id. at 1223 .

144. Id. at 1218 (noting and adopting the district court's findings).

145. Id. at 1219.

146. Id.

147. Id.

148. 777 F.2d 520, 524 (9th Cir. 1985). Hancock has been cast into doubt by the Ninth Circuit's decision in Chemstar, Inc., v. Liberty Mut. Ins. Co., 41 F.3d 429 (9th Cir. 1994), petition for cert. filed, 63 U.S.L.W. 3599 (U.S. Feb. 6, 1995) (No. 94-1337), which predicted that California courts would adopt the manifestation trigger. However, Chemstar in turn has been weakcned by Montrose Chem. Corp. v. Admiral Ins. Co., 897 P.2d 1 (Cal. 1995), in which the California Supreme Court rejected the manifestation trigger for third-party liability insurance cases.

149. Hancock, 777 F.2d at $521 \&$ n.2.

150. Id. at 522 .

151. Id. at 522, 525. While Hancock involved the insurer's duty to defend rather than its duty to indemnify the insured, the same issue is involved: which trigger theory should apply?

152. Id. at 524 .

153. Id.

154. Id. 
and therefore multiple exposures, in this case there was only one exposure: the implantation of the heart valve. ${ }^{155}$

In Forty-Eight Insulations, the court had limited its holding to asbestosis on the ground that asbestosis was a disease that had long been known. ${ }^{156}$ However, asbestosis, like the bacteria-induced disease in Hancock, is a cumulative, progressive disease with delayed mamifestation. For that reason, it does not resemble the traditional types of injuries that CGL policies were designed to cover. ${ }^{157}$ As noted above, the standard CGL policy is not equipped to deal with the problems associated with delayed manifestation. ${ }^{158}$

Some courts have applied the exposure trigger in cases involving both bodily injury and property damage. In $T B G$, Inc. v. Commercial Union Insurance Co., ${ }^{159}$ the court held that coverage was triggered each time the plaintiff released hazardous material onto an adjacent field, thereby incurring environmental clean-up costs. The court chose the exposure trigger, rather than the continuous or the manifestation trigger, because each release of hazardous-waste material gave rise to liability, and therefore each release triggered coverage. ${ }^{160}$ The court rejected the continuous trigger, discussed below, because it would have forced insurers who provided coverage long after TBG had stopped releasing the contaminated waste material to bear liability. ${ }^{161}$

\section{Why the Exposure Trigger Should Be Abandoned}

Like the mamifestation trigger, the exposure trigger has the advantage of facilitating easy determinations of whether a given policy is triggered. However, the exposure-trigger theory suffers from flaws that make its use undesirable from a policy perspective.

The biggest problem with the exposure trigger is that it does not take into account continuous and cumulative injury and damage. The insurer on risk $^{162}$ will be liable for all damages stemming from the exposure. In other words, the insurer covering the period of time when exposure occurs must bear the entire cost up to policy limits, even though some of the damage may have occurred $\mathrm{m}$ other policy periods. Thus, the exposure trigger can

155. Id. The court also found that the language of the insurance clause supported the exposurc theory: " "all bodily injury . . . arising out of continuous or repeated exposure to substantially the same general conditions shall be considered as arising out of one occurrence." "The court further noted that "[t]his clause is a recitation of the exposure theory and the result in this case is, therefore, precisely what Admiral bargained for when entering into the policy with Hancock." Id. at 524 n.9.

156. 633 F.2d at 1223 n.21.

157. See id. at 1219 ("Cumulative disease cases are different from the ordinary accident or discase situation. ... The contracting parties would expect coverage to parallel the theory of liability.").

158. See id. at 1226 n.29.

159. 806 F. Supp. 1444, 1445, 1452-53 (N.D. Cal. 1990).

160. Id. at 1453.

161. Id.

162. 1 use the term "on risk" to denote the time period when an insurance policy is active. 
lead to inequitable results among the various insurers. The exposure trigger also runs contrary to the language of the typical CGL policy for much the same reason that the manifestation trigger does. ${ }^{163}$

\section{Continuous Trigger}

\section{Application of the Continuous Trigger}

Unlike the other three trigger theories, the "continuous trigger" always favors the imsured. Under this approach, CGL coverage is triggered during exposure to harm, manifestation of injuries, and the latent period in between. ${ }^{164}$ Thus, the insured can be confident of continual indemnification.

The first major case to present this trigger theory was Keene Corp. $v$. Insurance Co. of North America. ${ }^{165}$ Keene manufactured products containing asbestos, and as a result, faced over 6000 lawsuits claiming mjury caused by exposure to asbestos. ${ }^{166}$ The court held that the manifestation of injuries triggered coverage. ${ }^{167}$ But the court also held that inhalation exposure and exposure in residence (the latent period) triggered coverage as wéll. ${ }^{168}$

The Keene court's analysis proceeded from an economic nodel of the purpose of insurance: exchanging an uncertain loss for a certain loss. The uncertain loss is the potential legal liability, and the certain loss is the premium payment. ${ }^{169}$ Proceeding from this assumption, the court held that the manifestation of damage must trigger coverage, because it stemmed from a latent, unknown, and unknowable injury. Furthermore, the court held, not to cover such an injury would violate Keene's "very reasonable expectations." 170 The court then extended coverage backward through the latent period and exposure because of its fear that the insurance company would terminate coverage before manifestation of many cases of disease. ${ }^{171}$ Also, the post-exposure cases of injury were ones for which Keene would reasonably have expected coverage by CGL policies. ${ }^{172}$

An older case that is sometimes cited as supportive of the continuous trigger in the context of property damage is Gruol Construction Co. v. Insurance Co. of North America. ${ }^{173}$ In constructing a building for a third

163. Dykhouse \& Falik, supra note 125, at 506; see also supra text accompanying notes 131-133.

164. Some courts refer to this theory as the "triple trigger."

165. 667 F.2d 1034 (D.C. Cir. 1981), cert. denied, 455 U.S. 1007 (1982).

166. Id. at 1038 .

167. Id. at 1044 .

168. Id. at 1045 .

169. Id. at 1041 .

170. Id. at 1044 .

171. Id. at 1045-46.

172. Id. at 1046.

173. 524 P.2d 427 (Wash. Ct. App. 1974). 
party, Gruol negligently caused dry-rot damage. ${ }^{174}$ The construction took place in 1963, the sale of the building to the third party concluded in 1964, and the third party filed suit in 1968. ${ }^{175}$ During that time, Gruol had policies with three different insurers, all of whom refused to defend, inuch less indemnify, Gruol for the dry-rot damage. ${ }^{176}$

The court found that the dry-rot dainage coinprised an occurrence, noting that it was unexpected. ${ }^{177}$ The court suggested that had Gruol known about the conditions that led to the dry rot, it inight not have been able to clain that an accident occurred. ${ }^{178}$ The court determined that all three insurers were liable, "even though the initial negligent act (the defective backfilling) took place within the period of [the first insurer's] policy coverage."179 The court's analysis was terse, consisting merely of citations to older cases froin multiple jurisdictions holding that accidents inay be long processes and may have delayed effects. ${ }^{180}$ It also declared that "the resulting damage was continuous." 181

Finally, an often-cited, and often-criticized, California case using the continuous trigger is California Union Insurance Co. v. Landmark Insurance Co. ${ }^{182}$ The parties in California Union were two insurers, disputing which one owed coverage to the insured for damage caused by a leaking swimming pool. ${ }^{183}$ The leaking caused the slopes around the pool to collapse. ${ }^{184}$ The initial damage to the slopes was repaired, but no one realized that the pool was the cause of the dainage. ${ }^{185}$ Thus, the pool continued to leak, causing more damage. ${ }^{186}$ One of the insurers was no longer on risk when the cause of the weakening slopes was discovered. ${ }^{187}$

The court held that each insurer was jointly and severally liable for the full amount of damages, and ordered each to pay one-half because their limits were identical. ${ }^{188}$ In so holding, the court followed older cases that, in essence, adopted a semi-continuous trigger for fear of the "cut-and-run" phenomenon discussed earlier. ${ }^{189}$

174. Id. at 429 .

175. Id.

176. Id.

177. Id. at 430 .

178. Id.

179. Id.

180. Id.

181. Id.

182. 193 Cal. Rptr. 461 (Ct. App. 1983).

183. Id. at 463-64.

184. Id. at 463 .

185. Id.

186. Id.

187. Id. at 468.

188. Id. at 471 .

189. Id. at 468-69. The cases that the California Union court followed were Snapp v. State Farm Fire \& Casualty Co., 24 Cal. Rptr. 44 (Ct. App. 1962) and Harman v. American Casualty Co., 155 F. Supp. 612 (S.D. Cal. 1957). 


\section{Why the Continuous Trigger Should Be Abandoned}

Of the various trigger theories, the continuous trigger provides the broadest coverage to the insured. For this reason, it best serves the general rule of construing insurance policies so as to provide coverage. However, the decisions that most strongly support the continuous trigger have been widely criticized for two reasons, one of which is persuasive. ${ }^{190}$

First, the continuous-trigger rule has the potential to conflict with the "loss-in-progress" rule, which bars insurance for events that are neither contingent nor uncertain. ${ }^{191}$ However, the California Supreme Court found this argument unpersuasive, because all that the loss-in-progress rule required was that there be some contingency, and an "inevitable" event was still an insurable contingency or risk..$^{192}$

The biggest potential problem with the continuous-trigger theory is that of apportioming coverage liability. A continuous trigger can implicate several insurers for one occurrence. Generally, courts do not allow "stacking" of limits, ${ }^{193}$ but instead require the insured to choose one insurer for indemnification, and force that insurer to seek contributions from all others. ${ }^{194}$ In other words, courts applying the continous trigger impose joint and several liability. This approach makes one insurer bear the full loss and then seek indemnification, even though there is no guarantee that a subsequent court will be able to untangle the matter of apportionment. ${ }^{195}$

The California Supreme Court revisited the trigger-of-coverage issue in 1995 and concluded that the continuous trigger was appropriate for cases involving continuous, progressive damage. See Montrose Chem. Corp. v. Admiral Ins. Co., 897 P.2d 1 (Cal. 1995). note 129 .

For a more complete discussion of the "cut-and-run" phenomenon, see supra text accompanying

190. For criticism of Keene and California Union, see Hancock Laboratories, lnc. v. Admiral Ins. Co., 777 F.2d 520, 524-25 \& n.10 (9th Cir. 1985) (criticizing Keene and California Union); Abex Corp. v. Maryland Casualty Co., 790 F.2d 119, 124-26 \& nn.26 \& 35 (D.C. Cir. 1986) (finding Keene inapplicable and criticizing its approach); American Home Prods. Corp. v. Liberty Mut. Ins. Co., 565 F. Supp. 1485, 1490-91 n.1, 1510-11 (S.D.N.Y. 1983) (criticizing Keene), aff'd and modified, 748 F.2d 760 (2d Cir. 1984); Zurich Ins. Co. v. Northbrook Excess \& Surplus Ins. Co., 494 N.E.2d 634, 644-45 (Ill. Ct. App. 1986) (criticizing Keene), aff'd sub nom. Zurich Ins. Co. v. Raymark Indus., Inc., 514 N.E.2d 150 (Ill. 1987).

191. See, e.g., CAL. INs. CoDE $\S \S 22,250$ (West 1993); Vyn v. Northwest Casualty Co., 301 P.2d 869, 872 (CaI. 1956). In Chemstar, Inc. v. Liberty Mut. Ins. Co., 797 F. Supp. 1541, 1551 (C.D. Cal. 1992), aff'd, 41 F.3d 429 (9th Cir. 1994), petition for cert. filed, 63 U.S.L.W. 3599 (U.S. Feb. 6, 1995) (No. 94-1337), the court rejected the continuous trigger on the ground that it provided indemnification inconsistent with the loss-in-progress rule.

192. Montrose Chem. Corp. v. Admiral Ins. Co., 897 P.2d 1 (Cal. 1995).

193. "Stacking" has been defined as "obtaining for a single loss insurance proceeds from duplicate coverages." JERRY, supra note 5, at 678.

194. See Keene Corp. v. Insurance Co. of N. Am., 667 F.2d 1034, 1050 (D.C. Cir. 1981), cert. denied, 455 U.S. 1007 (1982); Armstrong World Indus., Inc. v. Aetna Casualty \& Sur. Co., 26 Cal. Rptr. 2d 35, 56-60 (Ct. App. 1993), rev. granted sub nom. In re Asbestos Coverage Cases, 866 P.2d 1311 (Cal. 1994).

195. See infra part IV.E.2. 


\section{Injury in Fact}

\section{Application of the Injury-in-Fact Trigger}

The "injury-in-fact" theory holds that coverage is triggered when damage actually occurs, regardless of when it is discovered. In cases of bodily injury or property damage with delayed manifestation, injury in fact typically takes place some time after exposure, but before manifestation.

The Second Circuit held in American Home Products Corp. v. Liberty Mutual Insurance Co ${ }^{196}$ that standard CGL language-which indicates that application to an injury "which occurs during the policy period"-can support only an injury-in-fact trigger. The court rejected manifestation because "[s]ome types of injury to the body occur prior to the appearance of any symptoms; thus, the manifestation of the injury may well occur after the injury itself." 197 It likewise rejected exposure as the trigger because an injury could occur during a policy period, with exposure occurring before the policy period. ${ }^{198}$ The Second Circuit modified the district court's holding so that "injury in fact" was not restricted to "diagnosable" or "compensable" injuries. 199 Thus, "a real but undiscovered injury, proved in retrospect to have existed at the relevant time, would establish coverage, irrespective of the time the injury became [diagnosable].' "200

In Abex Corp. v. Maryland Casualty Co., ${ }^{201}$ the District of Columbia Circuit followed American Home Products in adopting the injury-in-fact trigger, despite an earlier decision of the same circuit, Keene, ${ }^{202}$ which applied the continuous trigger. Like Keene, Abex involved the delayed manifestation of asbestos-induced injuries. ${ }^{203}$ The $A b e x$ court distinguished Keene on the grounds that Abex involved New York law, while Keene was not based on the laws of any state in particular. ${ }^{204}$ Therefore, Keene was relevant only if the court thought that the New York courts were likely to adopt its interpretation. ${ }^{205}$ Given that the Second Circuit had interpreted New York law in a conflicting way in American Home Products, the Abex court felt compelled to follow the Second Circuit. ${ }^{206}$

Various courts have extended the injury-in-fact trigger to claims of property damage. In Trizec Properties, Inc. v. Biltmore Construction

196. 748 F.2d 760, 764 (2d Cir. 1984), aff'd and modified, 748 F.2d 760 (2d Cir. 1984). This case involved DES and several other pharmaceuticals, rather than asbcstos. Id. at 762 .

197. Id. at 764 .

198. Id.

199. Id. at 765 .

200. Id. at 766 (alteration in original).

201. 790 F.2d 119, 121 (D.C. Cir. 1986).

202. Keene Corp. v. Insurance Co. of N. Am., 667 F.2d 1034, 1044-45 (D.C. Cir. 1981), cert. denied, 455 U.S. 1007 (1982). For a more detailed discussion of Keene, see supra part 11.C.

203. Abex, 790 F.2d at 121 .

204. Id. at 124 .

205. Id.

206. Id. at 121, 124-25. 
$\mathrm{Co}^{2}{ }^{207}$ the plaintiff filed a suit against the insured, Decks, for the negligent installation of a roof deck. Due to improper installation, the deck suffered numerous latent defects, including leaking and rusting. ${ }^{208}$ The plaintiff did not discover these defects until 1979, three years after the insurer's occurrence-based CGL policy with Decks had expired. ${ }^{209}$ The insurer argued that it did not have a duty to defend because the damages did not manifest themselves until after the policy expired. ${ }^{210}$ The court rejected this argument, holding that there was no requirement that damages inanifest themselves during the policy period. ${ }^{211}$

In Eljer Manufacturing, Inc. v. Liberty Mutual Insurance Co., ${ }^{212}$ the Seventh Circuit held that the installation of a defective product could be considered a "physical injury" to the property, even if the product does not cause any tangible change in property until years later. ${ }^{213}$ The product in question was a plumbing system sold to contractors all over the United States from 1979 to 1986 . Soon after sales began, people started to complain about leaks, and by 1990 , there were several hundred lawsuits involving almost 17,000 systems. $^{214}$ Not all of the lawsuits alleged leaks, however. Some plaintiffs claimed damages because the value of their properties had dropped due to the possibility of future leaks, because they had taken the precaution of replacing the systems before leaks could spring, or because they were afraid to turn on the water, and thus had been deprived of partial use of their homes. ${ }^{215}$ The trigger dispute between the insured and the insurers focused on these non-leak claims, particularly those where the owners had not replaced the systems. Liberty Mutual argued that dainage occurred, and therefore coverage should be triggered, when the individual plumbing system leaked, and that non-leaking damage occurred when the homeowners realized that their property value had been reduced, or when they replaced their defective systems. However, Liberty Mutual con-

207. 767 F.2d 810, 811 (11th Cir. 1985).

208. Id. at 812 .

209. Id. at 812-13. The policy obligated the insurer to pay damages for " "property damage ... caused by an occurrence." " (emphasis omitted). Occurrence was defined as " "an accident, including continuous or repeated exposure to conditions, which results in bodily injury or property damage neither expected nor intended from the standpoint of the insured.' " (emphasis omitted). Property damage was defined as " 'physical injury to or destruction of tangible property' occurring during the policy period." Id. at 812 .

210. Id. at 813 .

211. Id.; see also Staefa Control-System Inc. v. St. Paul Fire \& Marine Ins. Co., 847 F. Supp. 1460, 1473 (N.D. Cal. 1994) (holding that the "occurrence" within the meaning of a CGL was not the discovery of pollution damage, but the date the plaintiffs were injured when the pollution migrated onto their properties).

212. 972 F.2d 805, 814 (7th Cir. 1992), cert. denied, 113 S. Ct. 1646 (1993).

213. Under such a theory, the injury "occurs" as soon as the defective component is installed. This version of the injury-in-fact trigger resembles the exposure trigger.

214. Eljer, 972 F.2d at 807.

215. Id. 
tended that installation by itself was not a cause of damage. ${ }^{216}$ Many of the leaks did not occur until after Liberty Mutual's policies with Eljer had expired; furthermore, many people whose systems had not leaked but who realized their property value had dropped or who replaced their systems preemptively did not do so until after the expiration of Liberty Mutual's policies. ${ }^{217}$ Due to procedural constraints, however, the Seventh Circuit considered only the claims involving leaks and replaced systems. ${ }^{218}$

Judge Posner, in an economic analysis of the purpose of insurance and semantic analysis of policy language, concluded for the court that Liberty Mutual's interpretation of the policy would provide largely illusory coverage. ${ }^{219}$ Insurance is designed to spread risks, so that parties can pay a premium to avoid later problems. Once a risk becomes a certainty, insurance becomes useless. ${ }^{220}$ The court found that the last moment that the plumbing system still presented a risk of leaking was at installation. Once the system actually leaks, "the risk has turned into a certainty and cannot be spread by being insured."221

Second, the court looked at the term "physical injury" and concluded that it was meant to distinguish between physical and nonphysical injuries, rather than between physical injuries and noninjuries. ${ }^{222}$ The significance of the distinction was that the most plausible interpretation of the insurance policy was that "physical injury" encompassed "a loss that results from physical contact, physical linkage, as when a potentially dangerous product is mcorporated into another and ... must be removed, at some cost, in order to prevent the danger from materializing." 223

Of particular significance is the fact that the court looked specifically at the 1973 version of the CGL policy, which had changed the definition of "property damage" from the 1966 version's definition. ${ }^{224}$ The earlier version defined "property damage" as "injury to or destruction of tangible property." "225 The 1973 version, which is substantially similar to the language in the 1986 policy, defined "property damage" in two ways: (1) "physical injury to or destruction of tangible property" and (2) "loss of use

216. Id. at 808 .

217. Id.

218. Id.

219. Id. at 809 .

220. Perhaps the best example of this phenomenon is the intersection of health care insurance and AIDS. Once a person is diagnosed with AIDS, the need for future medical care is known with certainty to be extremely high. Therefore, there is no way to cancel risks by pooling among AIDS patients. See ABRAHAM, supra note 4, at 22-23.

221. Eljer, 972 F.2d at 809.

222. Id. at 810 .

223. Id.

224. Id.

225. Id. 
of tangible property which has not been physically injured or destroyed."226 The court determined that the second term, which was new, could not be meant to curtail the coverage for physical mjuries, and that coverage should remain at least as broad as it had been. ${ }^{227}$

The court did, however, limit its holding to situations where "[ $t]$ he expected failure rate [is] sufficiently high to mark the product as defective."228 The court suggested that a failure rate high enough to lead a rational owner to choose to replace the system would qualify as "suffciently high."229

Judge Posner's opinion mentioned but did not rely on the difference between asbestos injury, where the tangible mamifestation is delayed but the damage begins at once, and the so-called "ticking time bomb," where there is no damage until the "bomb" explodes. ${ }^{230}$ Instead, Posner pointed out that this distinction had little to do with the intent and purpose of the parties in drafting the insurance contract. ${ }^{231}$

Applying similar but less technical reasoning, the Second Circuit in Maryland Casualty Co. v. W.R. Grace \& Co. ${ }^{232}$ held that the installation of asbestos-based products into buildings constituted property damage. To remedy this damage, owners would have to remove or cover the asbestos, and in doing so, would affect the market value of the structures. ${ }^{233}$

\section{Practical Problems of the Injury-in-Fact Trigger}

The injury-in-fact trigger has the potentially serious problem of forcing the insured to prove when damages actually occurred. ${ }^{234}$ In a products liability case with delayed manifestation of damages and injuries, this burden of proof can be difficult, if not impossible, to meet:

226. Id. at 807 . The exact language in the 1986 policy is as follows: "'Property damage' means: (a) Physical injury to tangible property, including all resulting loss of use of that property; or (b) Loss of use of tangible property that is not physically injured." ABRAHAM, supra note 4 , at 448 .

227. Eljer, 972 F.2d at 812 .

228. Id.

229. In Eljer, however, only five percent of the systems sold were estimated as likely to fail in tortious circumstances. Id. at 807 .

230. Id. at 809 .

231. Id.

232. No. 91-9322, 1993 U.S. Dist. LEXIS 22383 (2d Cir. Sept. 1, 1993) at *31, withdrawn; superseded by 23 F.3d 617 (2d Cir. 1993), cert. denied, 115 S. Ct. 655 (1994).

233. Id. at *30-31. Put simply, "the 'decrease in market value merely reflects the recognition that something bad has happened to the building[, and that] "something bad" is the incorporation of the defective product." "Id. at $* 30$ (alteration in original).

234. See, e.g., Federated Mut. Ins. Co. v. Botkin Grain Co., 64 F.3d 537, 542 (10th Cir. 1995) ("[T]he insured has the burden of proving a loss of the type included in the general coverage provisions"); Chemstar, Inc. v. Liberty Mut. Ins. Co., 41 F.3d 429, 436 (9th. Cir. 1994) (noting that "California law places 'the burden of proof ... on ... the insured ... to prove that an event is within the scope of coverage" "); Peters Township School Dist. v. Hartford Accident \& Idem. Co., 833 F.2d 32, 37 (3d Cir. 1987) (noting that the insured's "prima facie case consists of showing that a loss was sustained and that the loss falls within the risks insured against"). 
The only problem with this Solomonian [theory] is that no one wants it. The principle [sic] reason is cost. If medical testimony as to asbestosis' origin would have to be taken in each of the thousands of asbestosis cases, the cost of litigation would be prohibitive. ... In addition, it is almost impossible for a doctor to look back and testify with any precision as to when the development of asbestosis "crossed the line" and became a disease. ${ }^{235}$

One commentator has argued that the solution for cases in which it is factually impossible to determine when danages or injuries actually occurred is to pro rate the liability among the insurers. ${ }^{236}$ This Comment argues that when a rule of convenience is desirable, courts should apply a modified version of that commentator's pro rata approach.

\section{E. Choosing a Coverage Trigger}

What may explain some of the variation in the trigger cases is the desire to inaximize coverage for the insured, as the Eagle-Picher court acknowledged. ${ }^{237}$ There is, however, a difference between a principle of law that causes ambiguities to be construed against insurers in a set way and a policy of construing ambiguities against insurers on a case-by-case basis. The latter is little inore than a post-hoc determination so as to make insurers lose all coverage disputes.

This Comment suggests that courts uniformly should adopt the mjury-in-fact test. ${ }^{238} \mathrm{~A}$ careful reading of the CGL policy language reveals an absence of support for the other trigger theories. Moreover, while the mjury-in-fact trigger suffers from certain real-world flaws relating to factual determinations, courts can adopt rules to deal with these difficulties.

\section{III}

\section{UNIFORM APPROACH FOR THE OCCURRENCE AND TRIGGER-OF-COVERAGE ISSUES}

This Comment proposes the following rule for products liability cases with multiple delayed-manifestation injuries or damages:

* A single occurrence can cause damage over a number of CGL policies. In determining the number of occurrences, courts should look to the underlying cause of liability from the point of view of

235. Insurance Co. of N. Am. v. Forty-Eight Insulations, Inc., 633 F.2d I212, I2I 8 (6th Cir. I980), clarified on other grounds on reh ' $g, 657$ F.2d 814 (6th Cir.), cert. denied, 454 U.S. II09 (I98I); see also Mraz v. Canadian Universal Ins. Co., 804 F.2d I325, I328 (4th Cir. 1986).

236. Ogburn, supra note I3I, at 240-43.

237. See supra notes $139-\mathrm{I} 40$ and accompanying text.

238. As with the issue of determining the number of occurrences, the most important point is that courts uniformly adopt a single theory for when coverage is triggered. See supra notes 29-31 and accompanying text.

This Comment is not the first to advocate the injury-in-fact trigger. See Ogburn, supra note 131, at 243. 
the insured as the earliest opportunity the insured had to avoid causing the damage. (R1)

* Such an occurrence can trigger more than one CGL policy. A policy is triggered if the occurrence caused damage during that policy's coverage period, regardless of whether other policies have been triggered by that occurrence. (R2)

* Each insurer is responsible for indemnifying the insured for liability stemming from damages and injuries that actually occur during that insurer's coverage period. (R3)

* Each policy triggered is subject to its individual deductible and policy limits. (R4)

This proposal mcorporates the rules previously argued for in determining the number of occurrences ${ }^{239}$ and trigger of coverage. ${ }^{240}$ Parts R1 and $\mathrm{R} 2$ deal with the occurrence issue, and part $\mathrm{R} 3$ is based on the injury-in-fact trigger. Part R4 is an allocation rule.

A hypothetical example will illustrate the operation of the rule. Consider an insured covered over five years by five different one-year CGL policies, issued by insurers $\mathrm{A}$ through $\mathrm{E}$. Suppose that the insured manufactures a batch of defective widgets during the period covered by insurer A. During the year covered by insurer $B$, the widgets are shipped out to 100 consumers who incorporate the widgets into their homes. The defects in these widgets begin to damage the homes immediately, but the damage stays hidden and does not manifest itself until some time after purchase and imitial use, in periods covered by msurers $\mathrm{D}$ and $\mathrm{E}$.

Modelled on the causation rule for determining the number of occurrences, the proposed rule would view the 100 instances of damage as being a single occurrence stemming from the production of the defective batch of widgets. This single occurrence could trigger all five policies, if damages or injuries actually occurred during each coverage year. The rule, therefore, treats each insurer's coverage liability as being independent of any other insurer's liability.

To determine whether insurer $A$ is liable to the insured, the rule would require a determination of whether damages occurred during the period covered by insurer $A$. Because there was no such property damage during insurer A's coverage period, under the proposed rule's injury-in-fact trigger definition, insurer $A$ owes no indemnification to the insured.

Insurer $\mathrm{B}$, on the other hand, will be liable for indemnification for any injuries or damages occurring within its policy period because incorporation of the defective product constitutes property damage. ${ }^{241}$ Insurer B is liable

239. See supra part I.C.

240. See supra part II.E.

241. This analysis adopts Judge Posner's theory in Eljer that the incorporation of a defective product within a larger unit constitutes property damage to that unit. See supra notes 212-213 and accompanying text. 
to the insured, subject to its policy deductible and coverage linit, for the amount of damage suffered by the victims, measured in this case by the drop in property value.

In this example, insurer $\mathrm{C}$ covered a latent period, between initial exposure and manifestation. Whether insurer $\mathrm{C}$ is liable for indemnification depends on whether property damage actually occurred during this period. If the damage that eventually manifests itself is of Posner's "ticking tine bomb" variety, where damage occurs more or less instantly, ${ }^{242}$ then there would be no damage or injury during insurer C's coverage period. On the other hand, if the harm that later manifests itself results from slow, progressive damage, such as leaking sewage pipes or slidimg houses, then property damage would have occurred during the period covered by insurer $C$. Insurer $\mathrm{C}$ would be liable for the financial loss of the damages and injuries that occurred during its policy period, subject to its policy limits and deductibles.

The damages occurring in periods covered by insurers $\mathrm{D}$ and $\mathrm{E}$ would trigger those policies respectively, if damage actually occurred during those periods. Manifestation of damages, for example, would trigger coverage if it constituted its own form of damage. ${ }^{243}$

\section{A. Proration Formula for Unknown Liability}

In the event that the extent of damage or injury in each year cannot be assessed with any accuracy, the proposed rule allocates liability among insurers on a pro rata basis in proportion to the insurers' policy linits, with a provision for uninsured years.

The basic model, which does not take into account uninsured years, apportions the liability of the msurer covering year $i$ as

$$
\begin{aligned}
L_{i}= & {\left[\left[K_{i} /\left(K_{1}+K_{2}+\ldots+K_{N}\right)\right] * D\right]-d_{i} } \\
& \text { (equation (1)) })^{244}
\end{aligned}
$$

where $D$ represents the total amount of damages, $N$ is the total number of insurers on risk, $K_{i}$ represents the policy limit of the insurer covering year

242. See Eljer Mfg., Inc. v. Liberty Mut. Ins. Co., 972 F.2d 805, 809 (7th Cir. I992), cert. denied. 113 S. Ct. I646 (1993).

243. Manifestation could cause damage if the damaged object had cosmetic value. For example, in Chemstar, Inc. v. Liberty Mut. Ins. Co., 4I F.3d 429, 431 (9th Cir. 1994), petition for cert. filed, 63 U.S.L.W. 3599 (U.S. Feb. 6, 1995) (No. 94-1337), a labelling defect caused the wrong sort of plaster to be used indoors, leading to pitting of smooth plaster walls. This pitting was the manifestation of the damage, but it might have constituted its own damage to the value of the appearance of the plaster.

244. I have attempted to conform to standard scientific conventions in labelling variabies. In particular, I use $x$ to refer to a variable in the middle of a sequencc; and $n$ or $M$ to refer to the last variable in the sequence. 
$i_{i}{ }^{245} d_{i}$ represents the deductible of the policy issued by the insurer covering year $i,{ }^{246}$ and $L_{i}$ is that insurer's liability. ${ }^{247}$

To complicate matters, the typical insurance coverage dispute involves both primary and excess insurers. Excess coverage exists on top of primary insurance and comes into play when the primary insurance limit is exhausted. ${ }^{248}$ To reflect that insurance structure, the proposed rule treats $K_{i}$ as the combined poliey limit of the primary imsurer and the excess insurer covering year $i$. Any liability accrumg to that coverage year is applied first against the primary insurer, exhausting that coverage before drawing from the excess insurer. For example, suppose year $i$ is covered by a primary insurer up to $\$ 500,000$, and an excess insurer from $\$ 500,000$ up to $\$ 2$ million. $K_{i}$ would be $\$ 2$ million, representing the combined limits of the primary and excess insurer. If the resulting liability is $\$ 750,000$, the primary insurer covers up to its limit, exhausting its contribution, with the excess insurer covering the remaining damage liability, which is $\$ 250,000.249$

While it may seem unfair that the apportionment rule exhausts the primary insurer's coverage completely before tapping the excess coverage, this result is in fact consistent with the nature of the coverage provided by the

245. Alternatively, a court might define $K_{i}$ as the premium charged by the insurer covering year $i$. In Insurance Co. of Texas v. Employers Liab. Assurance Corp., 163 F. Supp. 143, 147 (S.D. Cal. 1958), the court used the premiums in prorating the liability among insurers.

A later court refused to follow this approach, however, stating that "upon reflection it appears that unless the insureds are in identical circumstances, there are too many variables affecting the premiums to permit them to form an adequate basis for an equitable adjustment ...." Ryder Truck Rental, Inc. v. Schapiro \& Whitehouse, Inc., 269 A.2d 826, 831-32 (Md. 1970) (quoting Cosmopolitan Mut. Ins. Co. v. Continental Casualty Co., 147 A.2d 529, 534 (N.J. 1959)). The Ryder case, however, dealt with different insureds covered by different insurers. In a case where there is a single insured, the Ryder court's fear of too many variables would not apply.

The advantage of using premiums, rather than policy limits, is that "[i]t is commonly known that the cost of liability insurance does not increase proportionately with the policy limits. The cost of increased limits is relatively small when compared to the cost of minimum coverage." Cosmopolitan Mut., 147 A.2d at 534. Thus, the Cosmopolitan Mutual court apparently felt that apportionment by policy limits would result in unfairness to insurers that provide higher limits, because those insurers would have received only slightly higher premiums than insurers providing lesser limits.

This argument misses the point of the insurance policy, which is to transfer a certain risk. While it may be true that the premiums are not much higher for greater limits, the insured is not concerned so much with the premium as with the limits. Moreover, using premiums leads to the problem that insurers may have different profit margins; as a result, the insurers charging a higher premium for more profit will bear a greater proportion of liability even though they are transferring the same risk.

In any case, the apportionment scheme will work with premiums, rather than policy limits, beeause it alloeates liability based on a factor common to the insurers. That factor can be policy limits, or it can be premiums.

246. This formula assumes that each insurer covers the same insured for the same length of time as every other insurer. If, on the other hand, the insurers cover different lengths of time, then the formula would take into account the fraction of risk for any partial years. Thus, if insurer 1 covered only half a year, then $K_{I}$ would reflect that fraction of coverage.

247. For an example of how the proration of liability would work, see infra Example 1 in app. A. For an example of what happens when there are different policy limits, see infra Example 2 in app. A.

248. ABraham, supra note 3, at 594.

249. For an example of how the proration of liability would work when there are primary and exccss insurers, see infra Example 5 in app. A. 
insurers. The excess insurer provides a layer of coverage above the primary insurer, and thus the expectations of the parties are that the excess insurer owes no indemnification until the primary imsurer's coverage is exhausted.

\section{B. Proration Formula for Uninsured Years}

In the event that the manufacturer does not possess CGL coverage for a period of time during which injuries or damages may have occurred, the proposed rule makes the insured bear its proportionate share of liability. That liability is computed as follows:

$$
\begin{aligned}
& D * n / N \\
& \text { (equation (2)) }
\end{aligned}
$$

As before, $D$ represents the total amount of damage and injury, $n$ represents the number of years without CGL coverage, and $N$ represents the total number of years of risk. The remaining amount of damage is then prorated, as explained above, among the insurers on risk.

Thus, if there were five years on risk, and in two of those the manufacturer was uninsured, then it would bear forty percent of the liability. The insurers would bear the remaining sixty percent of the liability, to be prorated according to their policy limits. ${ }^{250}$

\section{Allowance for Insurers to Prove Overallocation}

Finally, an insurer should be given the opportunity to prove that injuries or damages could not have occurred within the periods it covered, or that if damages or injuries did occur, they could not have exceeded a certain dollar amount. Proof of the latter limits an insurer's liability to less than that mandated by the pro rata formula.

If an insurer does prove that its liability should be less than that for which it would be liable under the pro rata formula, the remaining amount of damages should be reapportioned for indemnification on a pro rata basis among the remaiming insurers. ${ }^{251}$

IV

\section{Justifytng the Proposed Rule}

None of the cases discussed earlier allocated insurer liability as this Comnient proposes. ${ }^{252}$ Yet, this rule adheres more closely to the typical

250. For an example of how the proration of liability would work with uninsured years, see infra Example 3 in app. A.

251. For an example of how the formula handles a situation where an insurer proves the formula overallocated liability, see infra Example 4 in app. A.

252. The closest approach is that in Owens-lllinois, lnc. v. United lns. Co., 650 A.2d 974 (N.J. 1994). In that case, the New Jersey high court developed guidelines that suggested an approach similar to the rule proposed in this Comment. However, that court did not resolve clearly the issues of excess 
CGL policy language than other approaches, and promotes both efficiency and equity in the risk-allocative functions of insurance.

\section{A. Support from CGL Policy Language}

The typical CGL policy language supports the proposed rule's treatment of the occurrence and trigger issues. A CGL policy typically reads

We will pay those sums that the insured becomes legally obligated to pay as damages because of "bodily injury" or "property damage" to which this insurance applies. ... This insurance applies only to "bodily injury" and "property damage" which occurs during the policy period. The "bodily injury" or "property damage" nnust be caused by an "occurrence."253

Words and phrases in quotation inarks are defined in a later section of the insurance form. The key phrase for the purpose of this textual analysis, however, is "which occurs during the policy period." No matter how one defines "property damage" and "bodily injury," the policy language states unequivocally that the policy applies to damage and injury that take place during the policy period. By defining the triggering portion of the rule as the time when injuries actually take place, the rule remains faithful to the above policy language in a way that the use of other trigger theories would not.

Moreover, there is extrinsic evidence suggesting that the drafters of the CGL policy anticipated that a single occurrence iniglit trigger multiple policies. For example, Gilbert Bean, one of the drafters, stated that:

[T] he policy in force when a particular injury or damage takes place is the one which applies, regardless of wlien the causing accident took place. So if the injury or damage froin waste disposal should continue after the waste disposal ceased, as it usually does, it could produce losses on each side of a renewal date, and in fact over a period of years, with a separate policy applying each year. ${ }^{254}$

Travelers Indemnity Company's Liability Claims Manual recognizes the same principle that Bean did: "When the mjury is gradual, resulting from continuous or repeated exposures, and occurs over a period of time, coverage may be afforded under more than one policy-the policies in

coverage and uninsured years: "[W]e must repose a substantial measure of discretion in a master who must develop the formula that fairly refiects the risks assumed or transferred." Id. at 994.

253. ABRAHAM, supra note 3 , at 440 .

254. Anderson et al., supra note 20 at 729-30 n.147 (quoting Gilbert Bean, Assistant Secretary, Liberty Mutual Insurance Co., New Comprehensive General and Automobile Program: The Effect on Manufacturing Risks 6 (Nov. 15-16, 1965) (quoted in William Pendygraft et al., Who Pays for Environmental Damage: Recent Developments in CERCLA Liability and Insurance Coverage Litigation, 21 IND. L. REv. 117, 141 (1988))) (emphasis added). 
effect during the period of injury."2ss These statements lend support to the proposed rule's adoption of the injury-in-fact trigger.

Moreover, the proposed rule does not conflict with the "other insurance" clause, which is explained in a different section of the CGL insurance form. This "other insurance" clause governs the interaction between the CGL policy on risk and other policies that may cover the damage or injury, and comes into play only "[i]f other valid and collectible insurance is available to the insured for a loss" covered by the CGL policy. ${ }^{256}$ Thus, in the situation where an insured has several consecutive CGL policies with no overlapping coverage, the "other insurance" clause will not apply.

\section{B. Justifying the Stacking Element of the Proration Provision}

The apparent "stacking" provision of the proposed rule, on the other hand, may not seem justifiable from the CGL policy language. "Stacking" refers to the practice of adding together the policy limits for all insurers on risk and drawing indemnification from that aggregate linit. ${ }^{257}$ For example, a manufacturer who caused dannages over a five-year period might try to stack together five consecutive one-year insurance policies, each with a $\$ 1$ million policy limit, for total coverage of up to $\$ 5$ million. The manufacturer's liabilities would be drawn from this $\$ 5$ million sum until they were paid fully or the sum was exhausted. Courts have generally been unreceptive to this practice of stacking. ${ }^{258}$ In the example above, the insured would be fully indemnified for up to $\$ 5$ million of liability, even if $\$ 4$ million of the dainage occurred in a single policy period with a policy limit of $\$ 1$ million. Stacking inay force an insurer to pay for damages or injuries that occurred outside the policy period for which it was on risk. This practice therefore seemingly violates the requirement of covering only damage "occurring during the policy period."259

The true unfairness of stacking arises because the insured is being relieved of risks that it inay not have transferred. The proposed rule ininimizes that unfairness by requiring the insured to pay deductibles for each year of coverage. In other words, while the insured in the above hypotheti-

255. Id. at 730-31 (quoting Memorandum of Allied-Signal, Inc. In Support of lts Motion for Partial Summary Judgment and In Opposition to Travelers' Motion for Partial Summary Judgment at 209 (Mar. 21, 1989), Travelers Indem. Co. v. Allied-Signal, Inc., 718 F. Supp. 1252 (D. Md. 1989) (No. JFM-88890)).

256. ABraHAM, supra note 4 , at 445 .

257. See, e.g., Keene Corp. v. Insurance Co. of N. Am., 667 F.2d 1034, 1049-52 (D.C. Cir. 1981), cert. denied, 455 U.S. 1007 (1982).

258. See id. at 1049 ("That principle, however, does not require that Keene be entitled to 'stack' applicable policies' limits of liability."); Hickman \& DeYoung, supra note 20, at 301-03.

259. Where the damages can be determined factually, there is no stacking problem. In thc example above, the insured covering the period with the $\$ 4$ million of damages would be responsible for only $\$ 1$ million, the limit of its policy. The other insurers would not be responsible for any part of the $\$ 3$ million left. The rule thus avoids the conflict with policy language that is presented by conventional stacking. 
cal will be indemnified for up to $\$ 5$ million, the insured will still have to pay all five deductibles on each of those five insurance policies.

Admittedly, this type of stacking can, in certain circumstances, result in greater coverage than would be warranted under each policy if actual damages were known. That observation can only be inade theoretically, however, because the very fact that a pro rata approach is being used ineans that the actual damages cannot be determined. Thus, there is no way in any specific case to know whether the insured is receiving inore coverage than is warranted. More inportantly, this "benefit" stens from a situation that is out of the insured's control: the difficulty in proving when damages actually occurred. The alternative approach is to select a method of apportioning liability on a pro rata basis that provides a potential benefit not to the insured, but to the insurers. ${ }^{260}$ The approach suggested by this Comment follows inore squarely the judicial practice of construing policies to provide the insured with coverage by resolving annbiguities against the insurer. ${ }^{261}$

Most inportantly, the potential benefit from stacking that the insured receives does not ainount to double recovery. Double recovery refers to a situation where an insured recovers nore than the total extent of its liability or loss through inultiple insurance policies. Public policy treats double recovery with disfavor because it transforms insurance from a ineans of risk transfer into a gainble. ${ }^{262}$ The proposed rule's pro rata approach does not, however, lead to a greater recovery than the amount of the total liability. This fact is apparent from the way equation (1) is framed: the sun of the fractions that represent each insurer's portion of the liability inust add up to $1 ;{ }^{263}$ therefore, the total recovery cannot exceed the loss, $D .^{264}$

260. For example, one could use a single policy limit and then apportion the liability under that limit among all insurers on risk.

261. E.g., Globe Indem. Co. v. State, 118 Cal. Rptr. 75, 78 (Ct. App. 1974); JERRY, supra note 5, at 98-103, 566-67.

262. See Frost v. Porter Leasing Corp., 436 N.E.2d 387, 389 (Mass. 1982) ("Duplicative recovery is 'a result which the law has never looked upon with favor.' ") (quoting Travelers Ins. Co. v. Graye, 263 N.E.2d 442 (Mass. 1970)); JERRY, supra note 5, at 678 ("Under the principle of indemnity, an insured is allowed to recover from insurance no more than his loss.").

263. For a mathematical proof, suppose that there are $M$ insurers on risk, to whom liability is to be allocated. The insured's total recovery, $R$, is the sum of its individual recoveries from each insurer, 1 through $M$. Thus:

$$
R=L_{1}+L_{2}+\ldots+L_{M}
$$

where $L_{l}$ is the liability of insurer $i$ as given by equation (1), supra part Ill.A. Replacing each $L_{i}$ with its component parts (the right side of supra equation (1)) yields:

$$
\begin{aligned}
& \quad R=K_{1} * D /\left(K_{1}+K_{2}+\ldots+K_{M}\right)+K_{2} * D /\left(K_{l}+K_{2}+\ldots+K_{M}\right)+\ldots+K_{M} * D /\left(K_{I}+\right. \\
& \left.K_{2}+\ldots+K_{B}\right)
\end{aligned}
$$

Because these fractions all have the same denominator, they can be added directly:

$$
\begin{aligned}
& R=\left[K_{1} * D+K_{2}^{*} D+\ldots+K_{M}^{*} D\right] /\left[K_{1}+K_{2}+\ldots+K_{M}\right] \\
& R=D^{*}\left[K_{1}+K_{2}+\ldots+K_{M}\right] /\left[K_{l}+K_{2}+\ldots+K_{M}\right] \\
& R=D
\end{aligned}
$$

Q.E.D.

264. Actually, the insured recovers less than $D$, since it must pay the deductible for cach policy under which it recovers. 


\section{Support from an Economic Analysis of Risk}

As will be shown through economic analysis, the proposed rule distributes and transfers risk efficiently. Economic analysis assumes that contracting parties who operate in an optimal environment with perfect information will draft "perfect" contracts. Perfect contracts are those in which "every contingency is anticipated and the associated risk is allocated between the parties."265 Perfect contracts are ideal for satisfying the aims of the contracting parties because they are economically efficient. ${ }^{266}$

In reality, however, contracts are incomplete, and hence imperfect. ${ }^{267}$ It may be too costly or there may be insufficient information to anticipate every contingency. ${ }^{268}$ Economic analysis seeks to fill the gaps in incomplete contracts by considering ex post what terms the parties would have drafted in a perfect world. ${ }^{269}$

That approach can be applied to the analysis of incomplete insurance contracts. Insurance serves two primary functions: risk transfer and risk allocation. The concept of risk transfer is straightforward: one party pays another party a premium to bear a risk currently borne by the first party. In risk allocation, an msurer "attempt[s] to set a price that is proportional to the degree of risk posed by each insured."270 The proposed rule clearly and efficiently transfers the risk of liability from defective products and allocates that risk between the parties.

\section{Risk Transfer}

An economic analysis of the proposed rule should begin with an inquiry into the nature of the risk being transferred. The nature of the risk is best determmed by examining the difference between risk-aversion and risk-neutrality. ${ }^{271}$ Suppose an individual or a corporation has a probability $p$ of suffering a loss of $L$, where $p$ ranges between 0 and 1 . The expected loss for the entity is therefore $p^{*} L$. The actual loss, however, will be either 0 or $L$, depending on whether the loss occurs.

A risk-averse entity prefers the certainty of the expected loss $p * L$ to the uncertainty of the gamble between 0 and $L$. A risk-ncutral entity, on the other hand, is indifferent between the two choices. ${ }^{272}$ Thus, the risk

265. Robert Cooter \& Thomas Ulen, Law and Economics 229 (1988).

266. Id. at $230,232$.

267. See Gillian K. Hadfield, Weighing the Value of Vagueness: An Economic Perspective on Precision in the Law, 82 Calif. L. Rev. 541,547 (1994).

268. Id. at 547-48.

269. See CoOter \& ULEN, supra note 265 , at 240.

270. ABRAHAM, supra note 4, at 2.

271. See Abraham, supra note 3, at 58-62; James P. Quirk, lNtermediate Microeconomics 346-49 (2d ed. 1983); Hal R. Varian, Microeconomic ANalysis 158-60 (2d ed. 1984).

272. QUIRK, supra note 271, at 347; VARJAN, supra note 271, at 158-59. A third kind of entity is risk-loving, and prefers the gamble of 0 or $L$ to the expected loss of $p^{*} L$. CooreR \& ULEN, supra note 265, at 61; QUIRK, supra note 271, at 347; VARIAN, supra note 271, at 158. Risk-lovers are not important to the analysis of this Comment, however, because almost all entities become risk-averse 
involves the uncertainty of the loss, and the magnitude of the risk is reflected in the expected loss. The market for insurance develops in response to the insured's risk-aversion and the insurer's risk-neutrality.

CGL policies transfer this risk from the insured to the insurer. The premium charged by the insurer reflects the magnitude of the risk; an increase in the likelihood of the loss or in the magnitude of the loss will lead to an increase in the premium. ${ }^{273}$

One way to think about the risk of liability for defective products is to consider the probability in any given year that there will be lawsuits filed against the imsured, multiplied by the total liability of all the lawsuits. In this way, there will be a discrete risk every year, corresponding to the likelihood and magnitude of legal liability for that given year. This risk corresponds to a claims-made policy. ${ }^{274}$

The occurrence-based policy, on the other hand, looks to the liability resulting from certain actions which cause injuries or damages. Because Inanifestation of damage or injury is frequently delayed, this liability potentially spans several years. Thus, a risk exists corresponding to the probability $p$ that there will be damages and injuries, over $x$ years, multiplied by the total liability of all the damages and injuries, $L$. Thus, a CGL policy covering the entire period of $x$ years would transfer the risk of $p * L$ from the insured to the insurer.

Note, however, that $p$ is itself a function of $p_{l}, p_{2}, \ldots, p_{n}$, where $p_{l}$, $p_{2}, \ldots, p_{n}$ represent the separate probabilities that damages or injuries will occur during years $1,2, \ldots, n{ }^{275} L$, the total liability of all the damages and injuries stemming from the occurrence, is the sum of $L_{l}, L_{2}, \ldots, L_{n}$, where $L_{1}, L_{2}, \ldots, L_{n}$ represent the total damages that occur during years 1 , $2, \ldots, n$. Thus, there is a discrete risk equivalent to $p_{i} * L_{i}$ for each separate year $i$.

The proposed rule presumes that each CGL policy transfers the discrete risk for that year from the insured to the insurer. Thus, the insurer

when the stakes are sufficiently high. JERRY, supra note 5, at 11; RICHARD A. POSNER, ECONOMIC ANALYSis of LAw 12 (4th ed. 1992).

273. In a perfectly competitive market, of which there are admittedly few, if any, in the real world, the premiums will match the expected value of the loss, plus administrative costs. VARIAN, supra note 271 , at 161. A perfectly competitive market drives an insurance firm's long-run profits to zero. Id. In the absence of a perfectly competitive market, the insurer can earn a profit. Nevertheless, the premium will still be a function of the likelihood of the loss and the magnitude of the loss.

274. See supra note 100 and accompanying text.

275. It is important to note that $p$ is generally not the sum of the individual probabilities, unless the individual probabilities are disjoint, meaning that they are mutually exclusive. For example, if a card is drawn randomly from a complete deck of cards, the probability that it is a heart is disjoint from the probability that the card is a club, because a card cannot be both. Thus, the probability that the drawn card is a heart or a club is simply the sum of the individual probabilities. Where the probabilities are not disjoint, however, the probabilities cannot be added. In the same example, the probability that the drawn card is a heart is not disjoint from the probability that it is a queen; a card can be both a heart and a queen. Thus, the probability that the drawn card is a queen or a heart is not the sum of those individual probabilities. See Paul G. Hoel et al., Introduction to Probability Theory 4 (1971). 
covering year $i$ assumes, up to the coverage limit of the policy, the risk $p_{i} * L_{i}$. Mathematically, the proposed rule transfers risk clearly between insureds and insurers.

\section{The Impact of the Proposed Rule}

The impact of the proposed rule can be seen by comparing three scenarios: five consecutive one-year policies with limits of $\$ 1$ million each; one five-year policy with a $\$ 5$ million limit; and one five-year policy with a $\$ 1$ million limit. ${ }^{276}$ The second policy represents the saine coverage that would occur if the policies in the first scenario were stacked together. Because the insurer's risk is greater in the second example than the five insurers' risk in the situation with five consecutive policies, ${ }^{277}$ it would charge a higher premium than the total premiums charged for the five oneyear policies. ${ }^{278}$ The third exannple, on the other hand, should result in a much lower premium than the total premiums for the five one-year policies, because the insurer's maximum potential exposure is much lower. In sum, the third scenario's five-year $\$ 1$ million policy will have the lowest risk and therefore the lowest premiums, followed by the first scenario's five oneyear $\$ 1$ million policies and finally the second scenario's five-year, $\$ 5$ milhon policy.

The proposed rule provides an insured with the aunount of indemnification commensurate with the premiums it has paid. Of course, indemnifcation does not have to be tied solely to premiums. However, policies with different preiniums should be treated differently, because the premiums reflect the "risk" that the insurer is assuming.

The proposed rule proinotes efficiency by not overlapping any risk transfer. That is, the risks transferred by each CGL policy are different risks, and taken as a whole, represent the entire risk over the time period covered by all the policies. ${ }^{279}$ By transferring discrete and non-overlapping risks, the rule promotes efficiency by resulting in minimum premiuins. In contrast, an allocation rule that overlaps risks is problematic. First, the insured cannot recover under both policies for the shared risk, because that would be double recovery. ${ }^{280}$ Yet, by paying double premiums for that shared risk, the insured is not receiving its reasonable expectations; it is

276. For the purposes of this example, the deductible amount of the five-year policies is irrelevant.

277. The most significant way in which the risk is lower with five one-year policies is that the maximum potential loss to be covered is $\$ 5$ million. This loss occurs only if there is a $\$ 1$ million loss each year. If the losses are unevenly distributed, with some periods totalling less than $\$ 1$ million, then the total covered loss will be less than $\$ 5$ million.

278. The difference in premiums assumes that all other factors remain constant.

279. Note, however, that $p_{l}^{*} L_{l}+p_{2} * L_{2}+\ldots+p_{l}^{*} L_{l}>p * L$. This is true because the risk $p * L$ covers only two situations: a loss of 0 or a loss of $L$. It does not cover the possibilities in betwecn those outcomes, such as a loss of $1 / 2 * L$. The sum $p_{l} * L_{l}+\ldots+p_{n} * L_{n}$, on the other hand, covers a wider spectrum of possibilities, and therefore the expected loss is greater.

280. See supra note 262 and accompanying text. 
paying for something it cannot receive. ${ }^{281}$ Second, by not delineating each insurer's liability clearly, such a rule results in litigation as insurers squabble to avoid liability. ${ }^{282}$ The proposed rule avoids these problems.

\section{Risk-Allocative Aspects of the Proposed Rule}

The proposed rule also helps to serve another nnajor purpose of insurance: risk allocation. As discussed above, the premium charged for transferring the insured's risk is a function of the expected loss of the risk: the greater the expected loss, the higher the premium. Risk allocation also atteinpts to deal with two major asymmetrical information probleins, adverse selection and moral hazard.

\section{a. Risk Allocation}

Risk allocation works by pricing different risks at different rates. High-risk activities result in high premiuns, leading the insured to select an efficient level of risk transfer. ${ }^{283}$ Because the premiun reflects the risk being transferred from the insured to the insurer, if the cost of the premiun exceeds the benefit that the insured derives froin the risk-creating activity, the insured will decrease its risk-creating activity. In particular, a rational insured will decrease its activity to the point where the marginal cost of the activity is equal to the marginal benefit of the activity. ${ }^{284}$ In this exanple, the marginal cost of the activity is reflected by the marginal increase in the premium.

Efficient risk allocation requires premiums that accurately reflect the risk being transferred. If the premiums are not accurate, a variation of the problem of adverse selection can create inefficiencies. ${ }^{285}$ Adverse selection refers to the problem that occurs when an insurer cannot distinguish between higher-risk insureds and lower-risk insureds. If the insurer charges a premium that represents the average risk of the two groups, the lower-risk insureds will pay a higher premiun than their expected losses, and they will choose not to purchase insurance at that rate. ${ }^{286}$ As a result, the insurer will be left with high-risk insureds, whose expected losses exceed the average premiums. Unless the insurer can reverse this trend, it will go out of busi-

281. Naturally, if risks overlapped from policy to policy, insurers would have to charge higher premiums to compensate for the greater risks and uncertainties created by the overlapping situation.

282. For estimates of the transaction costs created by litigation over insurance coverage disputes, see Owens-Illinois, Inc. v. United Ins. Co., 650 A.2d 974, 993 (N.J. 1994) (estimating insurance litigation costs at $\$ 500$ million annually, and as high as $70 \%$ of total cleanup costs in environmental litigation).

283. Agraham, supra note 4, at 2.

284. See COOTER \& Ulen, supra note 265 , at 25-26.

285. According to Professor Abraham, "a key to achieving an efficient allocation between the insurance and loss prevention methods of protecting against risk is the pricing of insurance coverage in accordance with expected loss. If pricing is inaccurate, then the allocation between these two methods will not be optimal." ABrahaM, supra note 3, at 12.

286. ABRAHAM, supra note 4, at 3-4; JeRRY, supra note 5, at 14. 
ness, because it will be paying out more in coverage payments than it takes in from policy premiums. ${ }^{287}$

The proposed rule potentially promotes efficient risk allocation by providing more detailed actuarial information for the insurers. As claims are filed against an insured and factual determinations are made as to liability, the insurers covering that insured will receive more information concerning the year-by-year details of injuries and damages. The insurers can thereby price the insurance more accurately ${ }^{288}$ Of course, this advantage is lost when courts must turn to proration, because by hypothesis the factual determination is too difficult to carry out. Nevertheless, the fact that insurers might establish an upper limit on damages occurring in their coverage period $^{289}$ suggests that even with apportionment, the proposed rule will create some year-by-year damage information.

It is possible that the proposed rule will create more information than would be efficient. Insurers will not subdivide risk groups when the costs of determining those divisions outweigh the benefits gained. ${ }^{290}$ However, because these costs of detailing the year-by-year damages and injuries must be incurred regardless, the additional information may be seen as a benefit.

Finally, the proposed rule advances the risk-allocative aspects of insurance by providing an incentive for the insured to reduce its risk classification. Because the losses of the insured during the current period will affect its premiums for future periods, ${ }^{291}$ the insured has an incentive to reduce its risk of damage- or injury-causing activity, particularly if it is the party best able to determine how to do so. ${ }^{292}$ It will, of course, only reduce those risks if the cost of doing so is offset by a marginal reduction in its premiums. ${ }^{293}$

287. Note that the insurer cannot escape this problem by raising its premiums. Raising premiums will serve only to drive away the least risky of the high-risk insureds, thus continuing the cycle.

288. The additional information can help the insurer set appropriate premiums either through its predictive value for risk classification, or through its historical value for experience rating, which "uses the loss experience of the insured during one period to help set the premiums charged in the following period." ABRAHAM, supra note 3, at 72.

289. See infra part IV.D.3.

290. ABRAHAM, supra note 3, at 69; JeRRY, supra note 5, at 14.

291. This explanation is a bit simplified, considering the reality that businesses often switch CGL insurers from year to year. As a result, there is an empirical question as to how easily such information is transferred from insurer to insurer. Of course, information developed during the course of a trial will generally be contained in the public record and will be easily available to any insurer.

292. ABraham, supra note 3, at 73. Professor Abraham discusses another possible classification scheme, that of feature rating. Feature rating uses observable characteristics of the insured to set the premiums. Id. at $7 \mathrm{I}-73$. Feature rating is preferable to experience rating when the insurer, and not the insured, is in the better position to determine how to reduce risk. Id. at 73.

Intuitively, a manufacturer seeking CGL coverage should be in a better position to determine where the greatest risks in its production process exist and how it can most efficiently reduce those risks.

293. See id. at 79-80. This principle underlies Judge Leamed Hand's famous opinion in United States v. Carroll Towing Co., 159 F.2d 169 (2d Cir. 1947), in which he described negligence as failing to take sufficient precaution, where the burden of that precaution, $B$, was less than the expccted damage, $p^{*} L$, where $p$ is the probability of injury and $L$ is the magnitude of injury. Carroll Towing, 159 F.2d at 173. Judge Hand did not make clear whether he meant that total or marginal quantities should be used; 


\section{b. Moral Hazard}

The proposed rule also provides deterrence against moral hazard. Moral hazard is the problem that sometimes results because the insured, after transferring its risk of loss to the insurer, still retains some control over whether the loss will occur. ${ }^{294}$ Economically speaking, "[o]nce an individual has purchased insurance, his or her incentive to control losses decreases. Moral hazard is the resulting tendency of an insured to underallocate. . .loss prevention after purchasing insurance."295 For example, an individual who has an insurance policy covering car theft might be less careful about locking the car doors. ${ }^{296}$ One way in which insurers control moral hazard is to include deductibles in the CGL policies. The deductible counteracts moral hazard to some degree by burdening the insured with an initial portion of the loss.

The proposed rule helps reduce the moral hazard problem by requiring the insured to absorb the deductible anount for each policy that is triggered. Without this feature of the proposed rule, once problems developed with a particular product the insured might fail to take steps to control the losses that continue into subsequent policy periods. ${ }^{297}$

Another means of controlling moral hazard is through risk classification. ${ }^{298}$ As discussed above, the proposed rule generates information that can provide incentives for the insured to reduce its risks. ${ }^{299}$ Thus, risk classification helps to control moral hazard by forcing the insured to consider the consequences of carelessness. To use the automobile example discussed earlier, ${ }^{300}$ an insured will not be less careful about locking her car simply because she carries theft insurance, because if her car is stolen, her preiniuns will increase after she files a clain.

In the saine way, the increased information resulting froin the proposed rule can lead to more efficient risk classification, and thus less mor-

however, law and economics suggests that marginal quantities will produce more accurate results. See Cooter \& Ulen, supra note 265, at 361-62, 615-16 (Question 8.5 a. \& answer to exercise 8.5 a.).

294. ABraham, supra note 3, at 14.

295. Id.

296. See Cooter \& ULEN, supra note 265 , at 66 ; see also ABraham, supra note 3 , at 14 (discussing moral hazard with respect to homeowner's insurance). Of course, the individual is probably not completely indifferent between having the insurer pay off the loss and retaining his or her car. First, the payment of the theft claim is likely to lead to higher insurance rates. Second, the emotional value of the car may exceed the amount for which it has been insured. Third, recovering from the insurance company involves transaction costs. Nevertheless, "other things being equal, insurance against loss will reduce your incentive to prevent the insured event from occurring, because you will have a tendency to treat your insurance coverage as though it were a good that can be consumed for free." Id.

297. Admittedly, the impact of the deductible on the moral hazard problem can be slight if the damages for that policy period are likely to be very great. On the other hand, there will be situations in which the additional deductibles do create sufficient deterrence to moral hazard. Thus, the proposed rule can reduce moral hazard in at least some instances.

298. Aвraham, supra note 3, at 15.

299. See supra part IV.C.3.a.

300. See supra note 296 and accompanying text. 
ally hazardous behavior on the part of insureds. Consider a situation where the insured incurs legal liability of $\$ 5$ million over a five-year period. The insured has five consecutive one-year CGL policies, each with a \$1 million coverage limit. Without a year-by-year determination of damages, the insured receives the same amount of indemnification whether the damages were $\$ 1$ million per year for five years, or $\$ 5$ million in one year. ${ }^{301}$

When year-by-year determinations of damages are made, however, the insured recovers different amounts depending on the temporal distribution of the damages. Damage patterns of $\$ 1$ million per year over five years result in full recovery, minus the deductibles; damages of $\$ 5$ million in one year result in recovery of $\$ 1$ million minus that policy's deductible. Thus, the insured has incentives to control large-scale losses beyond its coverage limits. Moreover, the insurers can factor that damage pattern into their premium rates, providing an additional incentive for the insured to control large-scale losses.

\section{Justifying the Proposed Rule's Proration}

The proposed rule admittedly suffers from the same problem as that underlying the injury-in-fact trigger: the real and tangible difficulty in establishing when damages actually occurred necessarily translates into difficulty in establishing the amount of damage within each separate policy period. To counter that problem, the proposed rule adopts a rule of convenience: liability is prorated when it cannot be established with certainty. Proration should, however, still take into account the risk being transferred. ${ }^{302}$

\section{Due Process Concerns}

One potential problem with prorating liability is that it creates a presumption that some damages occurred during each insurer's coverage period. Insurers might argue that this presumption denies them their due process rights "because there is no rational basis for the inference." 303 Now, in some instances, courts have shifted the burden of proof to defendants, but in these cases, the defendants have acted tortiously and have greater access to information than do plaintiffs. ${ }^{304}$ Thus, in the famous case

301. This result occurs whether one uses pro rata apportionment or not. Under pro rata apportionment, each insurer in this example is liable for one-fifth of the loss, or \$1 million. Under nonapportionment methods, the liability is capped at $\$ 1$ million, all placed on one insurer. Thus, the difference between the two methods is the amount that the insured recovers from the insurers. For an analysis of the problems of non-apportionment schemes, see infra part IV.D.

302. See supra equation (1), part III.A.

303. Sindell v. Abbott Lab., 607 P.2d 924, $931 \mathrm{n} .17$ (Cal.) (finding such an argument persuasive in the context of an attempt to shift the burden of proof to drug manufacturers in a products liability case), cert. denied, 449 U.S. 912 (1980).

304. Restatement (SECOND) OF TORTs § 433B(3) (1965) states that "[w]here the conduct of two or more actors is tortious, and it is proved that harm has been caused to the plaintiff by only one of them, 
of Summers v. Tice, ${ }^{305}$ the California Supreme Court shifted the burden of proving who had fired the shot that blinded the plaintiff from the plaintiff to the two defendants. ${ }^{306}$ The court based its decision on the inequity of not shifting the burden: "The injured party has been placed by defendants in the unfair position of pointing to which defendant caused the harm. If one can escape the other may also and plaintiff is remediless." ${ }^{307}$ The court also noted that the defendants were "wrongdoers" and "both negligent toward plaintiff." 308 Moreover, defendants typically "are in a far better position to offer evidence to determine which one caused the injury." 309

These justifications for shifting the burden of proof to the defendants, however, do not apply to insurers. In insurance coverage disputes based on products liability claims, if anyone is acting irresponsibly, it is the insured. The insurer has no causal connection to the victims' injuries or damages. More importantly, the insurer is not in a better position to offer information concerming the source of the victims' injuries or damages. Any information the insurer has relating to the insured's manufacturing techniques or other relevant facts is likely to come from the insured. Thus, the rationale for shifting the burden to defendants of disproving when injuries occurred in conventional tort situations cannot be extended to proration of liability among insurers.

In Sindell v. Abbott Laboratories, ${ }^{310}$ the California Supreme Court built on the Summers reasoning and apportioned liability on manufacturers of diethylstilbesterol (DES) on a market-share basis. ${ }^{311}$ As in Summers, the court felt that the defendants were more culpable than the plaintiff with regard to the inability to prove causation:

[P]laintiff is not at fault in failing to provide evidence of causation, and although the absence of such evidence is not attributable to the defendants either, their conduct in marketing a drug the effects of

but there is uncertainty as to which one has caused it, the burden is upon each such actor to prove that he has not caused the harm."

305. 199 P.2d 1 (Cal. 1948), overruled as stated in Jolly v. Eli Lilly Co., 751 P.2d 923 (Cal. 1988).

306. Id. at 5 .

307. Id. at 4 (emphasis added).

308. Id.

309. Id.; see also Ybarra v. Spangard, 154 P.2d 687 (Cal. 1944) (shifting burden of proof to defendants where the injury occurred while the plaintiff was unconscious and being operated on by the defendants).

310. 607 P.2d 924 (Cal.), cert. denied, 499 U.S. 912 (1980).

311. Id. at 936-37. Thus, a defendant with a $30 \%$ market share of the manufacturing of DES would pay $30 \%$ of the plaintiff's award. One of the major problems with using the market-share approach is that accurate figures for market share might be impossible to determine. Id. at 937-38 \& n.29. That problem does not exist with the proposed rule's pro rata apportionment, however, because that apportionment is based on the insurers' coverage limits or the policy premiums, which are easily available.

Under this theory, the liability of the manufacturers is several, and thus if there are manufacturers unable to pay their share of damages, the plaintiff will recover less than $100 \%$. See Brown v. Superior Court, 751 P.2d 470, 485-86 (Cal. 1988). 
which are delayed for many years played a significant role in creating the unavailability of proof. ${ }^{312}$

Further, the court felt that, as a policy matter, defendants were in a better position to absorb the cost of injuries across all consumers as a business cost. Placing the liability on defendants would also encourage them to improve the safety of their products. ${ }^{313}$

None of these reasons strongly apply to insurers, either. In the underlying products liability lawsuits against the insured, the victims suing are those who have suffered bodily injury or property damage as a result of the insured's products. In the subsequent insurance coverage dispute, on the other hand, the insured might be termed a "victim," but only in a very loose sense of the word. Certainly, the insurers' conduct plays no part in creating the problem of proving when damages actually occurred. ${ }^{314}$ Placing liability on the insurers does, in a sense, spread the cost among consuiners, but no more so than placing the liability on the manufacturer. The same is true with regard to providing incentives to develop safer products. There is, therefore, an admitted due process concern with proration, one that cannot be justified by mere reference to conventional tort rationales for burden shifting.

\section{Policy and Equity Concerns}

Nevertheless, pro rata apportionment among insurers is at least as defensible as a matter of policy and equity as is the use of market share apportionment for inultiple tortfeasors. First, pro rata apportionment by policy limits (or premium payments) is a much simpler factual inatter than is the determination of market shares. In Sindell, the court acknowledged "the practical problems" of the latter. ${ }^{315}$ A court applying pro rata apportionment need only look at the insurance policies to determine the relevant policy limits. Therefore, on a purely pragmatic level, pro rata apportionment is more easily achieved in insurance coverage disputes than in tort cases.

Second, and more fundamentally, it may be fair to apportion liability. In the absence of such a rule, the insured will be denied at least some of its CGL indemnification, even though it has paid yearly premiums. In a way,

312. Sindell, 607 P.2d at 936 (emphasis added).

313. Id.

314. For a fascinating analysis of the role causation and conduct play in notions of "liability," see Judith J. Thomson, Remarks on Causation and Liability, 13 Philosophy \& Pub. Afr. 101 (1984). Unfortunately, Professor Thomson's discussion is inapplicable here, because the dispute between the insured and insurers is contractual, not tortious.

315. Sindell, 607 P.2d at 937; see also Collins v. Eli Lilly Co., 342 N.W.2d 37, 48.49 (Wis.) (rejecting market-share liability due to the difficulty in defining market share fairly and accurately) cert. denied, 469 U.S. 826 (1984); cf. Goldman v. Johns-Manville Sales Corp., 514 N.E.2d 691, $699-701$ (Ohio 1987) (rejecting market-share liability because asbestos products were not fungible in the way that DES pills were). 
each of the other three triggers-manifestation, exposure, and continuousapplies an injury-m-fact analysis, but with different definitions of "injury." The exposure theory deems the injury to have occurred when the victin or property is exposed to the damage-causing agent. The manifestation trigger deeins the imjury to have occurred when it is discovered. Thus, these other triggers all simplify the fact-finding involved by taking certain shortcuts in determining when the injury occurred. A court applying the injury-in-fact trigger eventually will reach an outcome resembling that which would be produced by one of the other three triggers (or perhaps some variation thereof). The advantage of the injury-in-fact trigger is that it produces a more accurate, less arbitrary result. The disadvantage of the injury-in-fact trigger is that it consumes inore time and resources than the other triggers. Professor Abrahan1 has suggested alleviating this disadvantage by allowing courts to transform the per se triggers

into modified injury-in-fact triggers, tailored to categories of injury or damage processes but avoiding whenever possible the need to make claim-by-claim findings of fact regarding these processes. ... $[\mathrm{T}] \mathrm{o}$ the extent that the facts regarding an injury or damage process permit generalization across cases, this approach also will take advantage of some of the savings on fact finding and litigation costs that the per se triggers can achieve. ${ }^{316}$

Thus, the position that apportionment is unacceptable because it relies on factual assumptions that are unfair to the defendant would invalidate all trigger theories except injury-in-fact. This position is not logically consistent if it rejects the rule proposed by this Comment, and yet supports the manifestation, exposure, or continuous trigger. Those triggers also make factual assumptions that can not be justified anymore than those of the proposed rule.

On the other hand, it is logically defensible to argue for a strict injuryin-fact trigger, with no allowance for the insured's inability to prove when damages or injuries occurred. Such a position, however, leads to unnecessarily harsh results. The insured would receive no CGL indemmification, even though the injury or damage occurred sometime during the policies covered by the insurers in the litigation. For these insurers to benefit from the insured's inability to prove the exact time of a causal fact would enrich thein unjustly and would upset the reasonable expectations of the insured. ${ }^{317}$

In other settings, courts have dispensed with strict causation requirements in the interest of equity and justice. For example, in Cimino $v$. Raymark Industries, Inc., ${ }^{318}$ a district court resolved 2,298 clains of asbestos-induced injuries by sampling the results of 160 cases and then awarding

316. See Abraham, supra note 113, at 105-06.

317. See supra part 1.C.1.

318. 751 F. Supp. 649 (E.D. Tex. 1990). 
the average recovery to the remaining 2,138 plaintiffs. ${ }^{319}$ The defendants argued that such a practice violated their due process rights by denying them the ability to confront the plaintiffs in individualized trials. ${ }^{320}$ The court rejected the defendants' arguments, largely because it found that the defendants had adopted a "fortress mentality"; by litigating every case one-on-one, the defendant manufacturers could delay enough trials so that many plaintiffs would die before their claims reached trial. ${ }^{321}$ Thus,

319. Id. at 653. This description is a bit simplified, because the court in Cimino actually broke the 160 plaintiffs in the sample pool into five categories based on the type of disease contracted. Id. For the purposes of this Comment, however, that distinction is not relevant. For a detailed discussion of Cimino, see Michael J. Saks \& Peter D. Blanck, Justice Improved: The Unrecognized Benefits of Aggregation and Sampling in the Trial of Mass Torts, 44 STAN. L. Rev. 815 (1992). For a bricf critique of Saks and Blanck's reasoning with respect to consent, see Robert G. Bone, Statistical Adjudication: Rights, Justice, and Utility in a World of Process Scarcity, 46 VAND. L. REV. 561, 600-03 (1993).

320. Cimino, 751 F. Supp. at 665.

321. Id. at 651-52. Indeed, one could infer that the defendants sought to delay trials from their refusal to agree to the sampling technique. It is economically irrational for the defendants to rcsist sampling for any other reason. Given an accurate sampling procedure, the damages produced through a sampling process will equal the expected damages produced through litigating each claim individually. Because the defendants are the common factor in every trial, facing potential liability in each case, they are in the same position as insurance companies, able to apply the Law of Large Numbers to pool the risks in individual cases. There is a common perception that insurance companies are risk-takers, or risk-loving. As Professor Cooter explains, however, this perception is incorrect. Insurance companies are able to pool risks together, and the risks of extreme results cancel onc another out. This cancelling follows from the Law of Large Numbers. COOTER \& ULEN, supra note 265, at 65.

Putting aside for a moment the transaction costs involved in litigating every case, the Cintino defendants would prefer the gamble of trying every case only if they are risk-loving. Risk-neutral entities will be indifferent, and risk-averse entities will prefer the certainty of the sampled process. In real life, few people are actually risk-loving, particularly where the stakes involved are high. As a simple thought experiment, however, one can consider whether to accept a gamble in which there exists a $50 \%$ chance of doubling one's current wealth and a $50 \%$ chance of losing it all. The expected outcomes are the same, but few people would accept the gamble.

The defendants might argue that they truly are risk-loving. To test sueh a contention, one could examine whether they purchased insurance. Insurance exists because individuals are risk-averse; one exchanges an uncertain risk for a certain loss greater than the expeeted loss of the uncertain risk. Thus, if the defendants truly are risk-loving, they will not purchase insurance.

Moreover, once transaction costs are factored in, the expected costs from trying evcry ease excecd the costs to the defendant from the sampling method. As a result, the only rational explanation for the Cimino defendants' position is that their intent is to delay the processing of claims against them. Delay produces several benefits: (1) any damages they must pay as a result of future determinations of liability are discounted to present value; (2) some plaintiffs will die before reaching trial, reducing the damages in those instances; and (3) by forcing each plaintiff to litigate every issue, the defendants can drive the cost of litigation high enough to dissuade some plaintiffs with smaller claims from pursuing them. These reasons, particularly the second and third, seem unethical and in violation of Rule 11 of the Federal Rules of Civil Procedure.

The ABA Model Rules of Professional Conduct state that a lawyer can be subject to discipline for taking a frivolous position on an issue in a proceeding. MOdel Rules of Professional Conduct Rule 3.1 (1994). The comment to the applicable rule includes, as an example of a frivolous position, one taken solely to harass or maliciously injure another person. Id. at Rule $3.1 \mathrm{cmt}$. The Cimino defendants might plausibly argue that they want to try each case individually for reasons other than harassing the plaintiffs, thus escaping the literal meaning of the Model Rules. Nevertheless, the defendants secm to be deliberately delaying litigation, thereby violating the intent of the Model Rules.

Similarly, the Federal Rules sanction pleadings and motions that are "interposed for any improper purpose, such as to harass or to cause unnecessary delay or needless increase in the cost of litigation." 
Cimino is significant because the court did not require proof of causation by every single plaintiff..$^{322}$

\section{Insurers' Exemptions from Prorated Liability}

Note that the proposed rule takes into account uninsured years by making the insured bear its proportionate share of losses for uninsured periods. ${ }^{323}$ Without such a provision, the proposed rule would grant insureds a potential windfall, for they might receive full indemnification, even though damages or injuries clearly occurred during uninsured years. This part of the rule is not unfair to insureds either, because by electing not to purchase insurance for those uncovered years, the insureds did not transfer to the insurers the risk of liability for damages and injuries occurring during those years. ${ }^{324}$

It should not be ignored that im Cimino, the sampling technique resulted in the manufacturers paying the expected aggregate loss. Pro rata apportioninent similarly should result in the imsurers paying the same amount over a large number of cases as if the facts in each case had been established. ${ }^{325}$ Insurance companies are, of course, the ultimate beneficiaries of the Law of Large Numbers. ${ }^{326}$ Thus, for insurers to resist pro rata apportionment is irrational. ${ }^{327}$

Finally, the proposed rule gives the insurer the opportunity to prove that injuries or damages could not have occurred within the periods it covered, or that if damages or injuries did occur, they could not have exceeded a certain dollar amount. In an analogous setting in Sindell, the California Supreme Court applied market-share liability, but allowed each manufac-

FED. R. Civ. P. 11. As discussed above, the defendants' "fortress mentality" strategy can be attributed only to their desire to delay as many suits as long as possible. Rule 11 therefore seems to apply in spirit, if not in actuality.

322. Of course, the insurers in a coverage dispute do not appear to have the same motives for delay that the asbestos manufacturers did in Cimino. Moreover, the plaintiffs in coverage disputes are not tort victims, but rather the tortfeasors. Still, Cimino indicates that courts can dispense with actual causation proof in the interest of justice and equity.

323. See supra equation (2), part lli.A.

324. See Owens-Illinois, Inc. v. United Ins. Co., 650 A.2d 974, 993 (N.J. 1994) ("[A]ny allocation should be in proportion to the degree of the risks transferred or retained during the years of exposure.").

325. This assertion assumes a random distribution of damages across time.

326. See COOTER \& ULEN, supra note 265 , at 65 (explaining the Law of Large Numbers).

327. See supra note $32 \mathrm{I}$. It is important to note a difference in the role played by an insurance company as an insurer versus as a defendant in a coverage dispute. As an insurer, it profits by calculating the expected losses of its insureds and then charging a premium on top of that loss. QURRK, supra note 271, at 349-50. As a defendant, however, the insurance company is not in a position to profit, because it is not now selling a service. Thus, its decision whether to accept apportionment comes down to whether it seeks to litigate every case individually, even though in the long run, its liability will be the same under either approach. 
turer the opportunity to prove that "it could not have made the product which caused plaintiff's injuries."328

There are even inore coinpelling reasons for allowing insurers the opportunity to relieve themselves of liability for injuries or damages caused by an insured. As discussed earlier, the reasons for imposing pro rata liability on insurers are weaker than those for shifting the burden of proof to defendants in ordinary tort cases. Therefore, insurers should receive at least as inuch procedural protection as ordinary defendants receive.

Admittedly, this modification will not aid insurers in many instances. The very fact that a pro rata approach is being used ineans that the court could not determine whether the injuries or damages actually occurred during each of the periods in question. In soine other instances, however, it inay be easier for an insurer to prove that injuries could not have happened during the period in question than it is for an insured to prove that the injuries did occur. ${ }^{329}$

If an insurer does prove that its liability should be less than that for which it would be liable under the pro rata formula, the remaining amount of damages is reapportioned for indemnification on a pro rata basis among the reinaining insurers. This approach differs from that applied by the California Supreme Court in the follow-up case to Sindell, Brown v. Superior Court. ${ }^{330}$ In Brown, the court resolved an ambiguity in the market-share doctrine by holding that the liability of the manufacturers was several only, and not joint and several. ${ }^{331}$ It rejected the plaintiff's arguinent that "each defendant's liability should be 'inflated' in proportion to its market share in an amount sufficient to assure that plaintiff would recover the entire amount of the judgment."332 The court felt that such an approach would not be faithful to the Sindell court's goal of imposing on each DES manufacturer liability for damages that matched its responsibility for the injuries inflicted by its products. ${ }^{333}$

The reason for not "inflating" Inanufacturers' liabilities in the context of products liability is that the plaintiff in those cases need only join manufacturers with a "substantial" inarket share. ${ }^{334}$ Thus, the total market share

328. Sindell v. Abbott Lab., 607 P.2d 924, 937 (Cal.), cert. denied, 449 U.S. 912 (1980). For example, one manufacturer was dismissed when it demonstrated that it had not made DES until after the plaintiff was exposed to the drug. Id.

329. Consider a product defect that causes bodily injury with delayed manifestation. The injuries manifest themselves five years after exposure, with the injury in fact occurring at some point between exposure and manifestation. The insured cannot prove when the damages did occur, and the court applies pro rata liability. The insurer covering the first year after exposure may be able to show, through expert testimony, that the injury did not occur until at least two years after exposure. If so, that insurer is relieved of its share of the prorated liability.

330. 751 P.2d 470 (Cal. 1988).

331. Id. at 485-87.

332. Id. at 487.

333. Id.

334. Id. at 485; Sindell, 607 P.2d at 937. 
of all the defendants is less than $100 \%$, unless every manufacturer of the product in question holds a substantial market share and is joined by the plaintiff. ${ }^{335}$ Inflating the liability would therefore result in some defendants paying more than their share to cover those manufacturers who are not parties to the action, but who nevertheless hold some market share. This concern does not apply in the insurance coverage context, however, because there are no "missing" imsurers. ${ }^{336}$

Finally, insurers have the opportunity to show that the damages or injuries for which they are liable to indemnify fall within policy exclusions. ${ }^{337}$ Any applicable exclusions will relieve the insurer of indemnification liability, leaving the insured to absorb the full liability. ${ }^{338}$ Although harsh, this result is not at all unfair, because exclusions represent risks not transferred from insured to insurer.

\section{E. Problems with Other Allocation Approaches}

Three other common methods of allocating indemnification conflict with policy language or other legal principles and are inferior to this Comment's proposed rule. These methods are (1) pro rata allocation to all insurers on risk based on length of coverage; (2) joint and several liability;339 and (3) full liability on the insurer whose policy is triggered by the manifestation of damages or injuries. ${ }^{340}$

\section{Pro Rata Allocation by Length of Coverage}

Under the typical pro rata approach, courts allocate the damages among the insurers in proportion to the length of time that they provided coverage, relative to the length of the time that the damage spanned. Thus, in Scottsdale Insurance Co. v. American Empire Surplus Lines Insurance Co., ${ }^{341}$ the court allocated four-thirteenths of the liability to the defendant insurer and nine-thirteenths to the plaintiff insurer, based on the fact that the defendant had provided four months of coverage and the plaintiff had provided mine months of coverage during the thirteen months that the victims

335. Brown, 751 P.2d at 485.

336. Of course, an insurer might go out of business and be "missing" in that sense. However, unlike the tort market-share approach, which excuses manufacturers with an insubstantial, yet greater than zero share, the proposed rule includes all insurers on risk.

337. See ABraham, supra note 3 , at 442.

338. See, e.g., Wcedo v. Stone-E-Brick, Inc., 405 A.2d 788 (N.J. 1979) (applying business risk exclusion); Unigard Mut. Ins. Co. v. Argonaut Ins. Co., 579 P.2d 1015 (Wash. App. 1978) (applying expected or intended harm exclusion).

339. See Keene Corp. v. Insurance Co. of N. Am., 667 F.2d 1034, 1050 (D.C. Cir. 198I), cert. denied, 455 U.S. 1007 (1982); see also Earnest, supra note 20, at 76 (explaining the Keene decision).

340. A similar allocation theory could use the exposure trigger, placing full indemnification responsibility on tbe insurer on risk when exposure occurred.

341. 811 F. Supp. 210 (D. Md. 1993). 
were exposed to toxins. ${ }^{342}$ The court's reasoning was that the allocation should not be divided equally because "the periods of exposure which [the insurers] covered were of different lengths." 343 The court then cited a 1939 case in which the Second Circuit apportioned liability for a cargo of tobacco that had been damaged over time "on a proportion based upon the respective periods that they had provided coverage during the time which damage . . . had occurred." 344

This method of pro rata apportionment does not apportion liability consistent with the risks being transferred from insured to insurers due to the possibility of policies with different coverage limits. The Scottsdale court was concerned that a rule of equal apportionment of liability where insurers covered different lengths of time would prove extremely unfair in a situation where one insurer covered the bulk of the period during which the damage occurred. ${ }^{345}$ That same concern applies in the situation where the insurers have issued policies with different limits, because the higher the policy limit, the greater the risk being transferred.

Moreover, the Scottsdale system of apportionment, even if applied to policy limits rather than length of coverage, may provide less coverage than an insured reasonably expects. This truncation occurs because the total amount of coverage is merely that of one policy limit, even if the damage spans multiple policy periods.

\section{Joint and Several Liability}

Courts that have applied the continuous-trigger test to progressive damage cases sometimes apportion insurer liability on a basis resembling joint and several liability. ${ }^{346}$ In Keene Corp. v. Insurance Co. of North America, ${ }^{347}$ the Court of Appeals for the District of Columbia Circuit held that the insured could collect from any insurer "the full amount of indemnity that it is due, subject only to the provisions in the policies that govern the allocation of liability when more than one policy covers an injury."348 The court later stressed that its decision did not saddle a single insurer with

342. Id. at 211, 217-18; see also Insurance Co. of N. Am. v. Forty-Eight Insulations, Inc., 633 F.2d 1212, 1224-25 (6th Cir. 1980) (holding that liability and litigation costs among insurers would be apportioned on a pro rata basis), clarified on other grounds on reh'g, 657 F.2d 814 (6th Cir.), cert. denied, 454 U.S. 1109 (1981).

343. Scottsdale, 811 F. Supp. at 217.

344. Id. (discussing Export S.S. Corp. v. American Ins. Co., 106 F.2d 9, 12 (2d Cir. 1939), cert. denied, 309 U.S. 686 (1940)).

345. Id.

346. Joint and several liability covers situations where multiple defendants act in conccrt to injure a victim. The victim is then allowed to sue any or all defendants, and can recover the full amount of a judgment against any one, or more, of the defendants. Those defendants who are forced to compensate the victim can then sue the other responsible parties. KEETON, supra note 38, at $\S 47$; see e.g., Ravo v. Rogatnick, 514 N.E.2d 1104 (N.Y. 1987).

347. 667 F.2d 1034 (D.C. Cir. 1981), cert. denied, 455 U.S. 1007 (1982).

348. Id. at 1050 . 
full liability for an injury. The insurer paying the judgment could recover from other insurers subject to "other insurance" provisions. ${ }^{349}$ Thus, without labelling its approach as such, the court essentially imposed joint and several liability on the insurers. ${ }^{350}$

The Keene court justified joint and several liability by construing the CGL policy to cover the full cost of damage or imjury caused by an occurrence, so long as soine of the damage or injury took place during the insurer's policy period. One commentator points out two major problems with this analysis: first, it misreads the CGL policy language, and second, it fails to distinguish between "occurrence" and "property damage" (or "bodily injury"). ${ }^{351}$

Courts using the joint and several liability approach impose liability in this inanner because the insurers have agreed to "pay those sums that the insured becomes legally obligated to pay." 352 These courts reason that because the insured's legal obligation can span several years, the insurer's obligation should also. ${ }^{353}$ However, the rest of the CGL policy clause reads, "[A]s damages because of 'bodily injury' or 'property damage' to which this insurance applies. . . . This insurance applies only to 'bodily injury' and 'property damage' which occurs during the policy period." 354 Thus, a joint and several liability theory does not comport with the plain language of the policy. ${ }^{355}$

Courts adopting joint and several liability also "rel[y] on the definition of 'occurrence' as a justification." ${ }^{356}$ Because the occurrence can include a long-term exposure to continuous or repeated conditions, these courts believe that an injury spanning a long period of time would be covered under one policy. ${ }^{357}$ Such a reading of the policy confuses the concepts of injury and occurrence. ${ }^{358}$ The occurrence is the cause of the injury or dam-

349. Id. For a discussion of "other insurance" provisions, see supra note 256 and accompanying text.

350. See Ogburn, supra note 131, at 236 (calling the Keene approach an example of Joint and Several Liability).

351. Id. at 237-39.

352. ABRAhAM, supra note 4, at 440; Keene, 667 F.2d at 1050.

353. Ogbum, supra note 131, at 238 (discussing J.H. France Refractories Co. v. Allstate Ins. Co., 626 A.2d 502, 507 (Pa. 1993)); see also Keene, 667 F.2d at 1050.

354. Abraham, supra note 4, at 440 (emphasis added).

355. Ogburn, supra note 131, at 237-38.

356. Id. at 238.

357. Id.

358. Id. A good explanation of the difference between the occurrence and trigger-of-coverage issues is provided in Whittaker Corp. v. Allianz Underwriters, Inc., 14 Cal. Rptr. 2d 659 (Ct. App. 1992). In Whittaker, the appellant manufactured a compound used to help seal soda cans. In 1983, it switched anti-oxidants, resulting in a compound that was brittle and damaged cans. Id. at 661 . The issue in Whittaker, however, was not whether these events constituted one occurrence or multiple occurrences, but rather, whether the damage occurred during a period when Whittaker was covered by an insurance policy. Thus, as the court pointed out, it was a trigger-of-coverage issue. Id. at 662-63. The court further indicated that Whittaker's reliance on "occurrence" cases was misplaced, because those cases spoke to the "insurer's limitation of liability" per occurrence: "The number of relevant 
age; ${ }^{359}$ there is no requirement that the occurrence take place during the insurer's policy period for liability to attach.

Apart froin the two major problems of inconsistency with the policy language and the misunderstanding of "occurrence" noted above, there is an inconsistency inherent in the Keene court's use of joint and several liability. If the insurer who is found liable to the insured can collect from other insurers under the "other insurance" clauses of CGL policies, ${ }^{360}$ that recovery must be for either actual damages shown to have bcen sustained in other periods, or damages on a pro rata or equal contribution basis. However, if the insurer seeking contribution can show that actual damages occurred in a year covered by a different insurer, then the court should make the second insurer cover that loss. That is, if the time that damagcs occurred can be established factually, then there is no reason not to apply the injury-in-fact trigger.

Moreover, applying joint and several liability in this manner will necessitate two trials with overlapping background testimony: the initial coverage dispute between the msured and insurers, and a second suit to determine contributions. On the other hand, if the court intends to allow the first insurer to recover against other insurers on a pro rata or equal contributions basis, it might as well do so in the initial coverage-dispute trial, rather than start a second trial.

Joint and several liability, therefore, is not a preferable method of allocating liability among multiple imsurers. It is not faithful to the language of CGL policies, and it fails to promote efficiency in litigation; if anything, it burdens courts with additional litigation.

\section{Manifestation Trigger Allocation}

The manifestation trigger allocates the entire liability, up to coverage limits, to the insurer on risk at the time the damage or injury caused by the insured manifests itself. One obvious problem with this method of allocation is that it relies on the manifestation trigger, the weaknesses of which this Comment has analyzed. ${ }^{361}$

occurrences for the purpose of interpreting the per occurrence limitation of liability is different from the question of when the relevant occurrence happens for the purpose of determining if there is coverage at all, or whether coverage should be allocated to a particular policy period." Id. at 663 .

359. The CGL policy states: "The 'bodily injury' or 'property damage' must be caused by an 'occurrence.'" ABRAHAM, supra note 4, at 440.

360. The relevant section of the "other insurance" clause of the typical CGL policy reads:

If all of the other insurance permits contribution by equal shares, we will follow this method also. Under this approach each insurer contrihutes equal amounts until it has paid its applicable limit of insurance or none of the loss remains, whichever comes first. If any of the other insurance does not permit contribution by equal shares, we will contribute by limits. Under this method, each insurer's share is based on the ratio of its applicable limit of insurance to the total applicable limits of insurance of all insurers.

ABRAhaM, supra note 4 , at 446.

361. See supra part Il.A.2. 
However, aside from those difficulties, the manifestation trigger's allocation of liability is likely to be less efficient than that of the proposed rule. A comparison of a hypothetical insured covered by three different insurers over a three-year period will illustrate the problem. In this hypothetical, the total cycle of damage covers three years; that is, if damages or injuries have not occurred within three years after exposure, they will not occur.

As discussed earlier, the proposed rule transfers the risk $\left(p_{i} * L_{i}\right)$ from the insured to the insurer, where $i$ is the year in question. ${ }^{362}$ Thus, over the three year period, the total risk transferred from insured to insurers is $\left(p_{I} *\right.$ $\left.L_{1}\right)+\left(p_{2} * L_{2}\right)+\left(p_{3} * L_{3}\right)$. The manifestation trigger operates differently. Within each year $i$ of coverage, there is a probability $q_{i}$ that injuries or damages will manifest during that year. The liability for year $i$ is the sum of $L_{i}$ and $p_{i-1} * L_{i-1}$ if $i>1$. For the first year, the liability is just $L_{i}$. The liability must take into account the expected risk from previous years, because the first policy that is triggered is liable for all damages up to that point. ${ }^{363}$ Thus, the total risk transferred from insured to insurer is

$$
\left.\left(q_{1} * L_{1}\right)+\left(q_{2} *\left[\left(p_{1} * L_{1}\right)+L_{2}\right]\right)+\left(q_{3} *\left[\left(p_{1} * L_{1}\right)+\left(p_{2} * L_{2}\right)+L_{3}\right)\right]\right)
$$

Multiplying out, the risk becomes

$$
\begin{aligned}
& \left(q_{1} * L_{1}\right)+\left(q_{2} * L_{2}\right)+\left(q_{2} * p_{1} * L_{1}\right)+\left(q_{3} * L_{3}\right)+\left(q _ { 3 } * \left[\left(p_{1} * L_{1}\right)+\left(p_{2} *\right.\right.\right. \\
& \left.\left.\left.L_{2}\right)\right]\right)
\end{aligned}
$$

If $q_{1}, q_{2}$, and $q_{3}$ are relatively close to $p_{1}, p_{2}$, and $p_{3}$ respectively, then the manifestation trigger transfers additional risk in the second and third years, as shown by the terms $q_{2} * p_{1} * L_{1}$ and $q_{3} * p_{1} * L_{1}$ and $q_{3} * p_{2} * L_{2}{ }^{364}$

362. See supra part IV.C.1.

363. I have used the expected risk $p_{i \cdot l} * L_{i l-}$ rather than the full liability $L_{l \cdot l}$ for the previous year because the damages in the previous year(s) are uncertain. However, replacing the expected risk with the full liability will only tilt the analysis further against choosing manifestation trigger allocation.

364. It is possible, even likely, that one or two of the probabilities of manifestation of damage will be smaller than the probability of damage actually occurring. However, the probability of manifestation of damage in the last year should be greater than the probability of damage in the third year, because the manifestation must take into account the possibility of delayed manifestation of damages or injuries from earlier years.

In fact, over the entire cycle of damage, the probability that damage will not actually occur is equal to the probability that damage will not manifest itself. Thus, if $q_{l}$ and $q_{2}$ are less than $p_{l}$ and $p_{2}$, then $q_{3}$ must be greater than $p_{3}$. Moreover, the greater the difference is between $q_{1}$ and $q_{2}$, and $p_{1}$ and $p_{2}$, then the greater the difference will be between $p_{3}$ and $q_{3}$. This is true because, over the entire cycle of damage:

$$
\left(1-q_{l}\right) *\left(1-q_{2}\right) *\left(1-q_{3}\right)=\left(1-p_{l}\right) *\left(1-p_{2}\right) *\left(1-p_{3}\right)
$$

That is, the probability that no damage will manifest during the entire three-year period is equal to the product of the probabilities that damage not manifest in any of the individual years. Similarly, the probability that no damage will occur during the entire three-year period is equal to the product of the probabilities that damage not occur in any of the individual years. For a discussion of independence, see HOEL, supra note 275, at 6-7, 10,19 (proving that the probability that an event A will not occur is equal to 1 minus the probability that $A$ vill occur, and defining the probability of independent events to be the product of their individual probabilities). 
Intuitively, the insurers on risk in later years assume the risk of damages within their own periods, but also the risk of damages in earlier years that have yet to be discovered.

The flaw in the manifestation trigger's transferring this extra risk is that the extra risk theoretically results im higher premiums, yet it is risk that the insured does not need covered again, because the risk has been covered under other policies. To be precise, the proposed rule's allocation of risk is Pareto superior to that of the manifestation trigger. Rule B is Pareto superior to rule $\mathrm{A}$ if someone is better off and no one is worse off under rule $\mathrm{B}$ than rule A; a rule is Pareto efficient if there is no other rule that is Pareto superior to it. ${ }^{365}$ By shifting to the proposed rule from a rule of manifestation trigger and allocation, courts would make either the insured or the insurers better off without making anyone worse off. The extra benefit would come from the insured not having to pay extra premiums for duplicative risk transfer. The insured is no worse off, because it has transferred away its risk under the proposed rule. It can invest the premium money saved in other projects, and is thus made better off than before. The insurer, on the other hand, loses that extra premium. However, it is no worse off because since it no longer has to cover duplicative risks, it can take on other risks and recoup its lost value. ${ }^{366}$

Of course, Pareto efficiency does not justify any rule over another rule on purely normative grounds. Given any possible allocation of resourcesin this case, risk and premium payments-there are numerous states or rules that are Pareto efficient. ${ }^{367}$ For example, the social state where the msurer charges the same premiums and transfers more risks, corresponding to the msurer's receiving the full surplus value of the proposed rule, is Pareto efficient. So is the social state where the insured pays lower premiums corresponding to the insured receiving the full value of the surplus of the proposed rule. Pareto efficiency offers no criterion for comparing these two states, and thus it is an incomplete normative criterion. However, where one state is Pareto superior to another, as the proposed rule is to the

365. COOTER \& ULEN, supra note 265 , at $44-45$.

366. Alternatively, the insurers could charge the same amount of premiums, but beeause they are relieved of duplicative risks, they will be profiting more than they had been before. They are thus made better off than before, and the insured is no worse off, because it has still transferred its risk, and it is paying the same level of premiums.

367. See VARIAN, supra note 271, at 198-99. For example, consider the following social states, A and $\mathrm{B}$, in which two people, $\mathrm{X}$ and $\mathrm{Y}$, receive different amounts of money:

\begin{tabular}{c|cc}
\hline & A & B \\
\hline $\mathrm{X}$ & $\$ 20$ & $\$ 90$ \\
$\mathrm{Y}$ & $\$ 70$ & $\$ 20$ \\
\hline
\end{tabular}

Each of these states is Pareto efficient. In moving from state $A$ to state $B, Y$ loses $\$ 50$ and is therefore made worse off. Thus, state A is Pareto efficient. Conversely, in moving from state B to state A, X loses $\$ 70$. Thus, state B is also Pareto efficient. 
manifestation allocation, it is not difficult to compare the states and to judge one better than the other. ${ }^{368}$

The previous model oversimplifies the situation in that it presumes a determinate cycle of damages, from beginning to end. In the case of a company that is starting up, this presumption may not be unreasonable. With established companies, what is more likely to occur is that every insurer is simultaneously in the position of insurers 1 through 3 in the previous model. That is, each insurer might have to indemnify the insured for damages manifesting during that year but occurring over a span of earlier years, or it might be relieved of liability for damages occurring during its year, but manifesting later on. If that is indeed the case, then each insurer will be able to discount the carry-over terms by the probability that damage occurring in its coverage period will actually manifest in a future year.

Under this more complex model, the manifestation trigger is still inefficient. ${ }^{369}$ It requires the calculation of a second set of probabilities, namely that of nuanifestation of damages, labelled as $q_{1}, q_{2}$, and $q_{3}$ in the model. Calculating these additional probabilities involves additional administrative costs, but does not yield any additional transfer of risk over the proposed rule. Thus, the proposed rule is still Pareto superior, because it transfers the same risk without added administrative costs. ${ }^{370}$

In the end, the namifestation-trigger method of allocation, in addition to the problenis created by the trigger itself, leads to inefficient risk transfer, and for those reasons is inferior to the rule proposed by this Comment.

\section{CONCLUSION}

Justices O'Connor, Kennedy, and Souter of the United States Supreme Court once wrote: "Liberty finds no refuge in a jurisprudence of doubt." 371 Although that observation referred to efforts by conservative presidents to overturn the constitutional right to an abortion, it could just as easily have

368. The appeal of Pareto superiority is such that even John Rawls, a noted anti-utilitarian, would seem to choose state $A$ over state $B$ if state $A$ is Pareto superior. Rawls conceives of a fair distribution as one that is created under a "veil of ignorance." JoHN RAwLS, A THEORY OF JUSTICE $\$ 24$ (1971). The idea of the veil of ignorance is that individuals should divide resources under the assumption that they will not know what they will receive. Thus, the veil of ignorance forces the individuals to consider how they want to treat the worst-off individuals in society. See id. A state that is Pareto superior to another state will leave the worst-off individual at least as well off, and at least someone better off than before. Thus, even under the veil of ignorance, individuals will elect a Pareto superior state.

369. It also resembles a "claims made" policy, which violates the "occurrence" requirement. See supra note 100.

370. It is true that the proposed rule imposes different information costs on the court system through its use of the injury-in-fact trigger. However, the manifestation trigger's costs are ex ante, which means they cannot be divorced from the trigger. The proposed rule's informational costs are $e x$ post and can be dealt with through judicial rules of convenience, such as pro rata apportionment.

371. Planned Parenthood v. Casey, 112 S. Ct. 2791, 2803 (1992) (opinion of O'Connor, Kennedy, \& Souter, JJ.). 
referred to the quagmire of insurance coverage law created by multiple rules for occurrence and trigger-of-coverage issues. ${ }^{372}$

Ideally, one approach would solve all the problems raised by these issues. If such a rule exists, no court has invented it yet. Nevertheless, a single approach, despite its inherent weaknesses, has several advantages over the current system of conflicting caselaw. A uniform approach for insurance indemnification disputes obviates much repetitive and wasteful litigation and relitigation. Even if the state of the law has developed such that most states have settled trigger and occurrence rules, a disparity between states creates the incentive for litigants to contest the application of choice-of-law rules so as to secure a favorable state's rules. A reduction in the cost of litigating such disputes should result in lower overhead costs for insurers, creating lower premiums for insureds. Even if such financial benefits are not realized, a unified rule will lead to predictability in the law.

The rule that this Comnient proposes follows a natural reading of the language of the policy. Additionally, the proposed rule transfers risk from the insureds to the insurers clearly, and is Pareto superior to other suggestions. Although the rule suffers from a potential weakness in its difficulty of proof, courts can alleviate that problem by creating rules' of pro rata allocation among all insurers sharing the risk. These insurers should, however, be given the opportunity to escape liability by proving that damages or injuries could not have occurred durmg their policy periods.

It is possible, of course, that insurance companies do not want CGL policies interpreted in the proposed manner. They may not wish to assume the risk that the rule transfers. Or, proper calculation of premiums under the proposed rule may be too fact-intensive to justify the use of "occurrence-based" policies. If that is the case, however, insurers should refuse to offer occurrence-based policies, and instead turn to claims-made policies. Alternatively, insurers could draft the CGL policies using different language. ${ }^{373}$ Implementation of this rule will at least force the insurers to consider these alternatives. ${ }^{374}$

Similarly, one might suggest that if insureds simply remained with a single insurer, they would not need to litigate the trigger-of-coverage issue. Unfortunately, that is not the case. Without a clear rule, each party would still have the incentive to argue that the injuries or damage either occurred in one policy period or in multiple policy periods, depending on whether the

372. Indeed, Justice Scalia's response in Casey may be even more appropriate: "Reason finds no refuge in [a] jurisprudence of confusion." Id. at 2880 (Scalia, J., dissenting).

373. JERRY, supra note 5, at 97 (explaining that when forms outlive their usefulness, they are often revised in response to judicial opinions).

374. As noted carlier, implementation of this Comment's proposal will create retroactivity concerns. See supra note 23 . However, since the interests of the insureds and insurers are always adverse, any trigger rule applied to interpret a CGL policy will necessarily upset the expectations of onc side. Given the rule of contra proferentem, it is unreasonable to upset the expectations of the insurers. 
monetary value of the injuries was large in comparison to the deductible or to the coverage limit of the CGL policy.

Finally, it is important to realize that the problem of uncertainty in the law governing CGL policies affects more than just the insurers and manufacturers who sell and purchase such coverage. The disputes between such parties actually impose great externalities on society; the insureds pass part, if not all, of the cost of litigation on to consumers, and the court time wasted in duplicative litigation clogs the dockets. The benefits of the rule proposed by this Comment thus accrue not only to insureds and insurers, but also to society in general. 


\section{Appendix: Numerical Examples of the ApPortionment Formula}

This appendix works through several combinations of fact patterns involving multiple insurers and delayed manifestation of injuries to illustrate the operation of this Comment's suggested rule. The examples cover the basic situation, different CGL limits, uninsured years, cases where an insurer proves that the formula overallocates liability, and cases involving primary and excess insurance coverage.

\section{Example 1. The Basic Situation}

Suppose Acme Manufacturing ("Acme") produces widgets for mass distribution across the country. Unfortunately, back in 1990, it used a contaminated resin, and as a result, Acme produced a defective batch of widgets. These widgets were shipped to thousands of customers. These widgets began to fail immediately upon installation, although the resulting damage was undetectable at first. From 1990 to 1994, the damage caused by the widgets manifested at different times for different customers. By 1994, the damage totalled $\$ 20$ million, and the victims filed numerous suits against Acme.

Suppose Acme was covered by CGL policies every year from 1990 to 1994, by insurance companies B (1990), C (1991), D (1992), E (1993), and F (1994). All five CGL policies have the same limit of $\$ 2$ million and deductible of $\$ 50,000$. The rule of this Comment comes into effect because as a practical matter, it is impossible to determine how much damage occurred im each year, 1990 through 1994.

The rule apportions liability among the insurers in proportion to their policy limits, as measured against the aggregate policy limit.

$$
L_{i}=\left[\left[K_{i} /\left(K_{1}+K_{2}+\ldots+K_{N}\right)\right] * D\right]-d_{i}
$$

Thus, im this example, the sum of the policy limits is $\$ 10$ million (five policies, each at $\$ 2$ million). Each msurer is therefore liable for a fraction of the total loss corresponding to its policy limit divided by the total sum of policy limits. In this example, each insurer is liable for one-fifth of the total liability.

One-fifth of $\$ 20$ million is $\$ 4$ million. Thus, the rule of the Comment apportions $\$ 4$ million of liability to each insurer, B through F.

However, the policy limit for each CGL policy issued by insurers B through $\mathrm{F}$ contain a policy limit of $\$ 2$ million. Thus, each insurer's liability is capped at $\$ 2$ million.

Finally, Acme must also pay the deductible of $\$ 50,000$ for each policy that has been triggered.

Thus, Acme recovers $\$ 1.95$ million from each insurer, $B$ through $F$, as indemnification for damage that Acme's defective widgets caused from 
1990 to 1994 stemming from that one defective batch. Acme's total indemnification is $\$ 9.75$ million of the total $\$ 20$ million of damage.

\section{Example 2. Different CGL Limits}

Suppose the situation is as in Example 1, except that Acme's CGL policies with insurance companies $\mathrm{B}$ through $\mathrm{F}$ contained varying policy limits, as follows:

\begin{tabular}{lcc}
\hline YEAR & INSURER & LIMIT \\
\hline 1990 & B & \$1 million \\
1991 & C & \$2 million \\
1992 & D & \$2 million \\
1993 & E & \$3 million \\
1994 & F & \$2 million \\
\hline
\end{tabular}

To calculate each insurer's liability, we need to determine the sum of the policy limits. In this example, the sum is $\$ 10$ million. As before, each msurance company's share of the total liability is its policy limit divided by the sum of the policy limits.

Insurance company B's liability is therefore one-tenth of $\$ 20$ million, or $\$ 2$ million. However, insurance company B's liability is capped at its policy limit of $\$ 1$ million. Taking into account the deductible, insurer $B$ is liable to Acme for $\$ 950,000$.

Insurance company C's, D's, and F's liability is two-tenths of $\$ 20$ million, or $\$ 4$ million each. However, each insurance company's liability is capped at its policy limit of $\$ 2$ million. Taking into account the deductible, insurers $\mathrm{C}, \mathrm{D}$, and $\mathrm{F}$ are each liable to Acme for $\$ 1.95$ million.

Finally, insurance company E's liability is three-tenths of $\$ 20$ million, or $\$ 6$ million. However, insurer E's liability is capped at its policy limit of $\$ 3$ million. Taking into account the deductible, insurer $\mathrm{E}$ is liable to Acme for $\$ 2.95$ million.

Acme's total indemnification is $\$ 9.75$ million of the $\$ 20$ million in total damages.

\section{Example 3. Uninsured Years}

Suppose the situation is again as in Example 1, except that Acme was uninsured for 1991. The rule takes uninsured years into account by making the insured bear a proportionate share of liability, based on number of uninsured years measured against total number of years of damage liability.

$D * n / N$

In this example, there are a total of five years for which Acme has caused damage to third-party victims through defective widgets. For one of 
those years, Acme was uninsured. Thus, Acme bears one-fifth of the total damage by itself, or $\$ 4$ million.

The remaining $\$ 16$ million remains to be apportioned among the four insurance companies, $\mathrm{B}, \mathrm{D}, \mathrm{E}$, and $\mathrm{F}$. (Insurance company $\mathrm{C}$ did not provide Acme with insurance coverage in this example.)

The sum of the policy limits is $\$ 8$ million (four policies, each at $\$ 2$ million). Each insurer is therefore liable for a fraction of the total loss corresponding to its policy limit divided by the total sum of policy limits. In this example, each insurer is liable for one-fourth of the total liability.

One-fourth of $\$ 16$ million is $\$ 4$ million. Thus, the rule of the Comment again apportions $\$ 4$ million of liability to each insurer, B, D, E, and F.

However, the policy limit for each CGL policy issued by insurers B, $\mathrm{D}, \mathrm{E}$, and $\mathrm{F}$ contain a policy limit of $\$ 2$ million. Thus, each insurer's liability is capped at $\$ 2$ million.

Finally, Acme must also pay the deductible of $\$ 50,000$ for each policy that has been triggered.

Thus, Acme recovers $\$ 1.95$ million from each insurer, $B, D, E$, and F, as indemnification for damage that Acme's defective widgets caused from 1990 to 1994 stemming from that one defective batch. Acme's total indemnification is $\$ 7.8$ million of the total liability of $\$ 20$ million.

\section{Example 4. Overallocation}

Now suppose that the situation is as in Example 1, except that insurance company $B$ is able to prove that the formula overallocates liability to it. Specifically, insurer B is able to prove that Acme's defective widgets could not have caused more than $\$ 500,000$ worth of damage during 1990 .

Insurance company B's liability is fixed at $\$ 500,000$, minus $\$ 50,000$ for the deductible. Thus, insurer B must indemnify Acme for $\$ 450,000$.

The remaining $\$ 19.5$ million of damage is then reallocated among the other four insurance companies. In this example, the insurers all have equal policy limits; therefore, each insurer bears one-fourth of the $\$ 19.5$ million, or $\$ 4.875$ million apiece. Because this amount exceeds the policy limit for each insurer, those insurers ( $C$ through $F$ ) do not owe any increased indemnification.

Acme's total recovery is $\$ 8.25$ million of the total $\$ 20$ million.

\section{Example 5. Primary and Excess Coverage}

Finally, in this last example, suppose that Acme is covered as in Example 1 by insurance companies $B$ through $F$, each up to $\$ 1$ million, but that Acme also has purchased excess insurance coverage in some of the years in between 1990 and 1994. In particular, suppose that Acme's CGL coverage appears as follows: 


\begin{tabular}{|c|c|c|}
\hline YEAR & PRIMARY INSURER & EXCESS INSURER \\
\hline 1990 & B, $\$ 1$ million & none \\
\hline 1991 & C, $\$ 1$ million & $\mathrm{G}, \$ 1$ to $\$ 4$ million \\
\hline 1992 & $\mathrm{D}, \$ 1$ million & $\mathrm{H}, \$ 1$ to $\$ 3$ million \\
\hline 1993 & E, \$1 million & I, $\$ 1$ to $\$ 2$ million \\
\hline 1994 & $\mathrm{~F}, \$ 1$ million & $\mathrm{J}, \$ 1$ to $\$ 2$ million \\
\hline
\end{tabular}

To apply the Comment's apportionment scheme witl excess insurers, the rule treats the total coverage in a given year as if it were covered by one insurer, not two, and applies the rule as before in Example 2.

Thus, the total sum of policy limits, primary and excess, is $\$ 12$ million, from 1990 to 1994.

The liability allocated to 1990 is one-twelfth of the total damage; to 1991, four-twelfths of the total damage; to 1992, three-twelfths of the total damage; to 1993 and 1994, two-twelfths of the total damage each.

Within any given year, the allocated liability is applied against the primary insurer first, and any remainder is applied against the excess insurer. For example, the rule allocates three-twelfths of the total damage of $\$ 20$ million to 1992. Three-twelfths of $\$ 20$ million is $\$ 5$ million. The first $\$ 1$ million is covered by insurance company $\mathrm{D}$. The remaining $\$ 4$ million is covered by insurance company $\mathrm{H}$, but only from $\$ 1$ million to $\$ 3$ million. Thus, in 1992, Acme must bear $\$ 2$ million of the loss by itself. 
